\title{
Response of fine particulate matter concentrations to changes of emissions and temperature in Europe
}

\author{
A. G. Megaritis ${ }^{1,2}$, C. Fountoukis ${ }^{2}$, P. E. Charalampidis ${ }^{3}$, C. Pilinis ${ }^{3}$, and S. N. Pandis ${ }^{1,2,4}$ \\ ${ }^{1}$ Department of Chemical Engineering, University of Patras, Patras, Greece \\ ${ }^{2}$ Institute of Chemical Engineering Sciences (FORTH/ICE-HT), Patras, Greece \\ ${ }^{3}$ Department of Environment, University of the Aegean, University Hill, 81100, Mytilene, Greece \\ ${ }^{4}$ Department of Chemical Engineering, Carnegie Mellon University, Pittsburgh, PA 15213, USA
}

Correspondence to: S. N. Pandis (spyros@ andrew.cmu.edu)

Received: 2 January 2012 - Published in Atmos. Chem. Phys. Discuss.: 5 April 2012

Revised: 2 March 2013 - Accepted: 5 March 2013 - Published: 26 March 2013

\begin{abstract}
PMCAMx-2008, a three dimensional chemical transport model (CTM), was applied in Europe to quantify the changes in fine particle $\left(\mathrm{PM}_{2.5}\right)$ concentration in response to different emission reductions as well as to temperature increase. A summer and a winter simulation period were used, to investigate the seasonal dependence of the $\mathrm{PM}_{2.5}$ response to $50 \%$ reductions of sulfur dioxide $\left(\mathrm{SO}_{2}\right)$, ammonia $\left(\mathrm{NH}_{3}\right)$, nitrogen oxides $\left(\mathrm{NO}_{\mathrm{x}}\right)$, anthropogenic volatile organic compounds (VOCs) and anthropogenic primary organic aerosol (POA) emissions and also to temperature increases of 2.5 and $5 \mathrm{~K}$. Reduction of $\mathrm{NH}_{3}$ emissions seems to be the most effective control strategy for reducing $\mathrm{PM}_{2.5}$, in both periods, resulting in a decrease of $\mathrm{PM}_{2.5}$ up to $5.1 \mu \mathrm{g} \mathrm{m}^{-3}$ and $1.8 \mu \mathrm{g} \mathrm{m}^{-3}$ (5.5\% and $4 \%$ on average) during summer and winter respectively, mainly due to reduction of ammonium nitrate $\left(\mathrm{NH}_{4} \mathrm{NO}_{3}\right)$ (20\% on average in both periods). The reduction of $\mathrm{SO}_{2}$ emissions decreases $\mathrm{PM}_{2.5}$ in both periods having a significant effect over the Balkans (up to $1.6 \mu \mathrm{g} \mathrm{m}^{-3}$ ) during the modeled summer period, mainly due to decrease of sulfate ( $34 \%$ on average over the Balkans). The anthropogenic POA control strategy reduces total OA by $15 \%$ during the modeled winter period and $8 \%$ in the summer period. The reduction of total OA is higher in urban areas close to its emissions sources. A slight decrease of OA $(8 \%$ in the modeled summer period and $4 \%$ in the modeled winter period) is also predicted after a $50 \%$ reduction of VOCs emissions due to the decrease of anthropogenic SOA. The reduction of $\mathrm{NO}_{\mathrm{x}}$ emissions reduces $\mathrm{PM}_{2.5}$ (up to $3.4 \mu \mathrm{g} \mathrm{m}^{-3}$ ) during the summer period, due to a decrease of $\mathrm{NH}_{4} \mathrm{NO}_{3}$, causing although an increase of ozone concentration in ma-
\end{abstract}

jor urban areas and over Western Europe. Additionally, the $\mathrm{NO}_{\mathrm{x}}$ control strategy actually increases $\mathrm{PM}_{2.5}$ levels during the winter period, due to more oxidants becoming available to react with $\mathrm{SO}_{2}$ and VOCs. The increase of temperature results in a decrease of $\mathrm{PM}_{2.5}$ in both periods over Central Europe, mainly due to a decrease of $\mathrm{NH}_{4} \mathrm{NO}_{3}$ during summer $(18 \%)$ and fresh POA during wintertime (35\%). Significant increases of $\mathrm{OA}$ are predicted during the summer due mainly to the increase of biogenic VOC emissions. On the contrary, OA is predicted to decrease in the modeled winter period due to the dominance of fresh POA reduction and the small biogenic SOA contribution to OA. The resulting increase of oxidant levels from the temperature rise lead to an increase of sulfate levels in both periods, mainly over North Europe and the Atlantic Ocean. The substantial reduction of $\mathrm{PM}_{2.5}$ components due to emissions reductions of their precursors outlines the importance of emissions for improving air quality, while the sensitivity of $\mathrm{PM}_{2.5}$ concentrations to temperature changes indicate that climate interactions need to be considered when predicting future levels of PM, with different net effects in different parts of Europe.

\section{Introduction}

Atmospheric particles have adverse effects on human health and have been implicated in various air quality problems such as the formation of acid rain and acid fogs (Burtraw et al., 2007), visibility reduction (Seinfeld and Pandis, 2006) and changes of the energy balance of the planet. Fine 
particulate matter less than $2.5 \mu \mathrm{m}$ in size $\left(\mathrm{PM}_{2.5}\right)$, ozone, and other pollutants are subjected to a complex series of common emissions, meteorological processes and photochemical production pathways. Consequently changes in emissions of one pollutant can lead to changes in the concentrations of other pollutants. In addition, changes in meteorological conditions such as temperature could also influence the concentration and distribution of air pollutants through a variety of direct and indirect processes, including the modification of biogenic emissions (Constable et al., 1999), the change of chemical reaction rates, changes in mixing heights that affect vertical dispersion of pollutants, and modifications of synoptic flow patterns that govern pollutant transport.

Several studies have tried to quantify how the emissions changes of one pollutant can lead to changes in the concentration of others and to estimate these source-receptor relations in Europe (Simpson, 1995; Sutton et al., 2003; Sillman et al., 2003; Erisman et al., 2003; Jonson et al., 2006; Vautard et al., 2006; Berglen et al., 2007; Konovalov et al., 2008; Fagerli et al., 2008). Lövblad et al. (2004) investigated trends of the emissions of sulfur dioxide, nitrogen oxides and ammonia in Europe and the corresponding response of the major inorganic fine particulate components over the past 2 decades. They observed that between 1980 and 2000, $\mathrm{SO}_{2}$ emissions decreased approximately $70 \%$ while sulfate concentrations decreased around $50 \%$. Emissions of nitrogen oxides and ammonia also decreased $25 \%$ and $20 \%$ respectively with a non-linear response of ammonium nitrate. De Meij et al. (2009a) applied a three-dimensional chemical transport model (CTM) over Northern Italy and estimated the impact of $50 \%$ emission reductions of $\mathrm{NO}_{\mathrm{x}}, \mathrm{PM}_{2.5}$, $\mathrm{SO}_{2}, \mathrm{VOC}$ and $\mathrm{NH}_{3}$, for different source sectors, on $\mathrm{O}_{3}$ and $\mathrm{PM}_{2.5}$ concentrations. This study showed that the $50 \%$ reduction of $\mathrm{NO}_{\mathrm{x}}$ and $\mathrm{PM}_{2.5}$ emissions coming from road transport and non-industrial combustion plants is the most effective control strategy for reducing $\mathrm{PM}_{2.5}$ levels over Po Valley, leading to an average decrease of $1-6 \mu \mathrm{g} \mathrm{m}^{-3}$ and 1$4 \mu \mathrm{g} \mathrm{m}^{-3}$ respectively. Jonson et al. (2001) studied the impact on ozone and ozone precursors over Europe due to the combination of global and regional changes in anthropogenic emissions. Their results showed that the expected reductions in the emissions of ozone precursors in Europe from 1996 to 2010 would lead to reductions of ozone, during summer, in southern, central and eastern regions of Europe. However, in Northern and Western Europe ozone levels were predicted to increase. This increase was primarily attributed to reductions in European emissions in areas dominated by high $\mathrm{NO}_{\mathrm{x}}$ levels. Thunis et al. (2007) conducted an intercomparison modeling study at different scales, over several European cities in order to predict the response of $\mathrm{O}_{3}$ and PM in several emission scenarios for 2010. The authors focused on the importance of fine scale modeling for $\mathrm{O}_{3}$ and PM related to urban centers. A similar study was carried out by van Loon et al. (2007) covering the whole European continent. Several studies, investigating the response of ozone and fine particu- late matter to changes of the major precursor emissions, have focused on different regions of North America (Russell et al., 1986; Jiang et al., 1996; Meng et al., 1997; Tonnesen, 1998; Chock et al., 1999; Stein and Lamb, 2000, 2002; Blanchard et al., 2001, 2007; Pun and Seigneur, 2001; Ngyen and Dabdub, 2002; Mueller et al., 2004; Kleeman et al., 2005; Pun et al., 2008; Tsimpidi et al., 2008; Makar et al., 2009). Tsimpidi et al. (2007) applied a three-dimensional CTM, PMCAMx, over the Eastern US to evaluate the response of $\mathrm{PM}_{2.5}$ mass concentrations to changes in $\mathrm{SO}_{2}$ and $\mathrm{NH}_{3}$ emissions for a summer and a winter period. They found that $\mathrm{NH}_{3}$ emission control during winter is an effective control strategy, while in the summer reductions in $\mathrm{SO}_{2}$ yield the largest reduction of $\mathrm{PM}_{2.5}$. Similar results for $\mathrm{NH}_{3}$ reductions were reported by Pinder et al. (2007) who calculated that the $\mathrm{NH}_{3}$ control strategy would be particularly cost effective in the winter.

The role of climate change on the concentrations of ozone, particulate matter and other pollutants and the impact of various climate change scenarios on air quality over Europe has been the subject of several studies (Tuovinen et al., 2002; Langner et al., 2005; Ordonez et al., 2005; Szopa et al., 2006; Forkel and Knoche, 2007; Giorgi and Meleux, 2007; Jacob and Winner, 2009). Forkel and Knoche (2006) used an online regional coupled atmospheric-chemistry model in order to investigate possible effects of global climate change on the near-surface concentrations of photochemical compounds in Southern Germany. They showed a $10 \%$ increase on average daily maximum ozone concentrations during summer mainly due to an increase of temperature and biogenic emissions along with a decrease of cloud water and ice. A regional CTM was used by Meleux et al. (2007) to investigate the effects of climate change on summer ozone levels over the European region, under different IPCC emissions scenarios (IPCC, 2007). Their study showed a substantial increase of ozone concentrations during summer in future climate conditions, mostly due to higher temperatures and reduced cloudiness and precipitation. They also addressed the importance of temperature-driven increase in biogenic emissions on ozone production. In a global study by Heald et al. (2008), the authors used a global atmosphere-land model to investigate the sensitivity of secondary organic aerosol (SOA) concentration to changes in climate and emissions under the year 2100 IPCC A1B scenario. They predicted increases of SOA levels in the future climate, mainly due to increase of biogenic SOA, which were estimated to rise around $35 \%$ in Europe. In addition, Carvalho et al. (2010) used downscaled meteorology generated by a global circulation model (GCM) in a regional CTM to study the impact of climate change on the air quality over Europe and Portugal, using the IPCC A2 scenario for the future. Their modeling system predicted that the response of $\mathrm{PM}_{10}$ to the future climate varies in space and time with increases of $\mathrm{PM}_{10}$ levels predicted mainly over the continental regions.

The main objective of this study is to quantify how fine particulate matter $\left(\mathrm{PM}_{2.5}\right)$ responds to emissions changes of 
its precursors and how a change on temperature would influence its concentrations. For this purpose we apply a threedimensional CTM (PMCAMx-2008) over Europe. Threedimensional CTMs are well suited for this purpose because they link emissions and meteorology to $\mathrm{PM}_{2.5}$ concentrations through descriptions of the physics and chemistry of the atmosphere. The PMCAMx-2008 model includes state-of-theart organic and inorganic aerosol modules which make it well suited for the purpose of this study. In addition, the model uses newly developed emissions inventories from both anthropogenic and biogenic sources in order to better understand the effectiveness of each control strategy on $\mathrm{PM}_{2.5}$ levels and to predict correctly the respective response. The PMCAMx-2008 performance has already been evaluated (Fountoukis et al., 2011) against high time resolution aerosol mass spectrometer (AMS) ground measurements taken from various sites in Europe as well as airborne measurements from an aircraft field campaign over Europe (Morgan et al., 2010) during the European Aerosol Cloud Climate and Air Quality Interactions (EUCAARI) intensive periods (Kulmala et al., 2011).

The remainder of this paper is organized as follows. First, there is a brief description of PMCAMx-2008 and the details of its application in the European domain. In the next section, the temporal and spatial characteristics of the effectiveness of $\mathrm{NH}_{3}, \mathrm{SO}_{2}, \mathrm{NO}_{\mathrm{x}}$, anthropogenic VOCs and anthropogenic $\mathrm{OA}$ emissions reductions on the concentration of the $\mathrm{PM}_{2.5}$ components are discussed. The response of the individual OA components to these emissions scenarios is also analyzed. The effects of temperature change are quantified in the following section. Finally the effectiveness of each emissions reduction scenario as well as the relative significance of the temperature change on $\mathrm{PM}_{2.5}$ levels, for the different periods are discussed.

\section{The PMCAMx-2008 CTM}

\subsection{Model description}

PMCAMx-2008 (Murphy and Pandis, 2009; Tsimpidi et al., 2010; Karydis et al., 2010) uses the framework of the CAMx air quality model (ENVIRON, 2003) which simulates the processes of horizontal and vertical advection, horizontal and vertical dispersion, wet and dry deposition, and gasphase chemistry. The gas-phase chemistry is described by the SAPRC99 mechanism (Carter, 2000; ENVIRON, 2003) which includes 211 chemical reactions of 56 gases and 18 free radicals. For the aerosol processes, three detailed aerosol modules are used: inorganic aerosol growth (Gaydos et al., 2003; Koo et al., 2003), aqueous phase chemistry (Fahey and Pandis, 2001) and SOA formation and growth (Koo et al., 2003; Murphy and Pandis, 2009). These modules employ a sectional approach that dynamically models the size evolution of each aerosol constituent across 10 size sections varying from $40 \mathrm{~nm}$ to $40 \mu \mathrm{m}$.
Three main approaches are available in PMCAMx-2008 for the simulation of inorganic aerosol growth. In the "bulk equilibrium" approach the bulk inorganic aerosol and gas phase are assumed to be always in equilibrium. At a given time step the amount of each species transferred between the gas and aerosol phases is determined by applying the aerosol thermodynamic equilibrium model ISORROPIA (Nenes et al., 1998) and is then distributed over the aerosol size sections by using weighting factors for each size section based on their surface area (Pandis et al., 1993). The advantage of this approach is its speed, simplicity and stability. The second approach ("hybrid" approach) assumes equilibrium for the fine particles $(<2.5 \mu \mathrm{m})$ and solves the mass transfer differential equations for the coarse particles (Capaldo et al., 2000). The most accurate but computationally demanding method is the "dynamic" approach where mass transfer is simulated explicitly for all particles (Pilinis et al., 2000). In this work we use the bulk equilibrium approach. In this approach the coarse mode nitrate chemistry is included (e.g. reaction of $\mathrm{NaCl}$ with $\mathrm{HNO}_{3}$ forming $\mathrm{NaNO}_{3}$ ), but assuming an average PM composition.

PMCAMx-2008 includes a state-of-the-art organic aerosol module which is based on the volatility basis set framework (Donahue et al., 2006; Stanier et al., 2008). The model simulates the partitioning of primary emissions assuming primary organic aerosol to be semivolatile. Nine surrogate POA species with effective saturation concentrations at $298 \mathrm{~K}$ ranging from $10^{-2}$ to $10^{6} \mu \mathrm{g} \mathrm{m}^{-3}$ are used following the approach of Shrivastava et al. (2008). POA is simulated in the model in two types, "fresh" (unoxidized) POA and oxidized POA (OPOA). For the intermediate VOC (IVOC) emissions we followed the approach of Tsimpidi et al. (2010) and Shrivastava et al. (2008), in which the IVOC emissions are proportional to the emitted primary OA mass. Due to the difficulty in measuring mass in this volatility range (it is emitted and remains largely in the gas phase), emission inventories do not include these compounds. Thus we add an additional 1.5 times the original POA mass emission rate to the intermediate volatility organic gas emission rate following several prior studies (Robinson et al., 2007; Murphy and Pandis, 2009; Hodzic et al., 2010; Tsimpidi et al., 2010). The IVOCs can then be oxidized by $\mathrm{OH}$ and may go to lower volatility and condense. SOA consists of organic aerosol of anthropogenic (aSOA) and biogenic (bSOA) origin. The SOA volatility basis-set approach (Lane et al., 2008a) used in the current version of the model includes four SOA species for each VOC with 4 volatility bins $\left(1,10,100,1000 \mu \mathrm{g} \mathrm{m}^{-3}\right)$. In addition, the model treats all anthropogenic organic species (primary and secondary) as chemically reactive. Chemical aging through gas-phase $\mathrm{OH}$ reaction of OA vapors is modeled. The parameters that we used in this study were taken from Murphy and Pandis (2009).

For the simulation of wet deposition the model uses a scavenging coefficient approach in which the local rate of concentration change within or below a precipitating cloud is equal 
to the product of the concentration of a pollutant and the respective scavenging coefficient. The scavenging coefficient is determined differently for gas and aerosol species following Seinfeld and Pandis (2006). For dry deposition, PMCAMx determines a deposition velocity for each land use type, for each given species, particle size, and grid cell, and then linearly combines them according to the fractional distribution of land use. The deposition flux is used as the lower boundary condition in the vertical dispersion algorithm. For the gas phase species, the resistance model of Wesely (1989) is used. The deposition velocity is calculated from three resistances in series: the aerodynamic resistance $r_{\alpha}$, the quasi-laminar resistance $r_{b}$, and the surface resistance $r_{\mathrm{s}}$. The surface resistance is further expressed as several more serial and parallel resistances that depend upon the physical and chemical properties of the surface in question. Many of these resistances, such as the stomatal resistance $r_{\mathrm{st}}$ vary also with temperature. Over water, the surface resistance is parameterized following Kumar et al. (1996) and Sehmel (1967). For aerosol particles the resistance approach of Slinn and Slinn (1980), as implemented in UAM-AERO (Kumar et al., 1996), has been adopted in PMCAMx.

\subsection{Modeling domain and inputs}

PMCAMx-2008 was applied over Europe covering a $5400 \times 5832 \mathrm{~km}^{2}$ region with $36 \times 36 \mathrm{~km}$ grid resolution and 14 vertical layers covering approximately $20 \mathrm{~km}$ (Fig. 1). The necessary inputs to the model include horizontal wind components, vertical diffusivity, temperature, pressure, water vapor, clouds and rainfall, all created using the meteorological model WRF (Weather Research and Forecasting) (Skamarock et al., 2005). The performance of WRF for Europe against observed meteorological variables has been the topic of a number of recent studies (Jimenez-Guerrero et al., 2008; de Meij et al., 2009b; Im et al., 2010; Argueso et al., 2011; Garcia-Diez et al., 2012) showing good agreement in comparison with observations. The concentrations of the major PM species used as boundary conditions of the domain in this study were taken from Fountoukis et al. (2011) and are based on measured background concentrations in sites close to the boundaries (e.g. Zhang et al., 2007; Seinfeld and Pandis, 2006).

Updated anthropogenic and biogenic hourly emission gridded fields were developed and evaluated for the European domain for gases and primary particulate matter (Table 1). Anthropogenic gas emissions include land as well as international shipping emissions and were developed by the TNO team during the EUCAARI project (Denier van der Gon et al., 2010) as a continuation of the work in GEMS and MACC. The major improvement was the development of the Pan-European Carbonaceous Aerosol Inventory improving the emissions estimates of anthropogenic particulate organic and elemental carbon (Kulmala et al., 2011). A detailed description of the emissions temporal variations and NMVOC

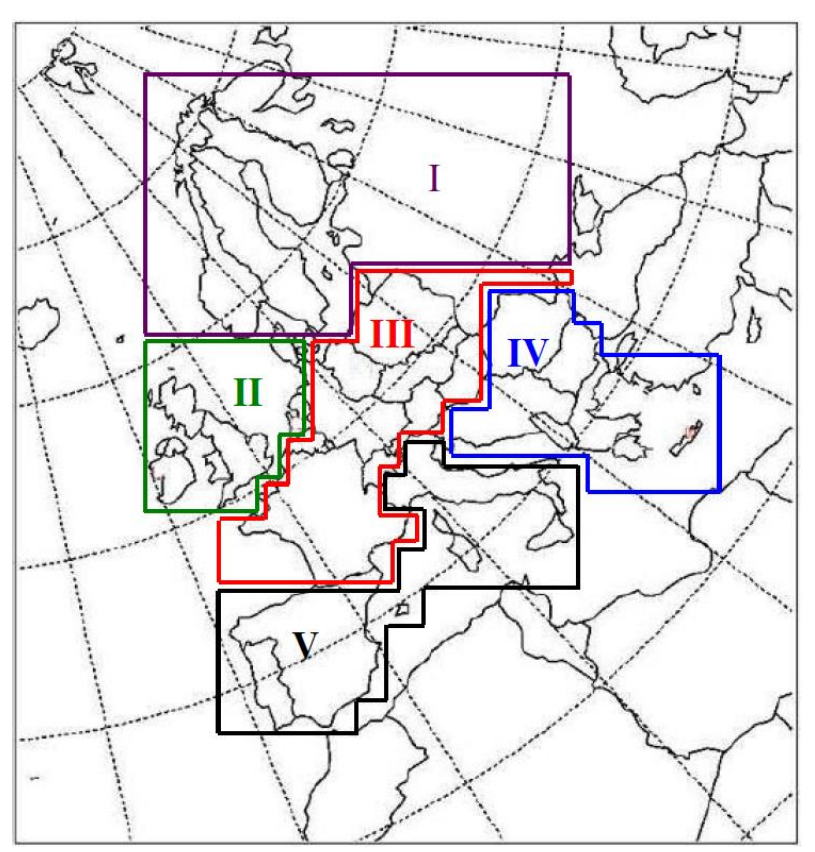

Fig. 1. Modeling domain of PMCAMx-2008 for Europe. The location of the five regions used for the investigation of the spatial dependence of the $\mathrm{PM}_{2.5}$ responses to emissions and temperature changes are also shown ( $\mathrm{I}=$ North Europe, $\mathrm{II}=\mathrm{UK}$ and Western Europe, III = Central Europe, IV = Balkans, V = Southwest Europe).

emissions composition is provided elsewhere (Schaap et al., 2005; Visschedijk et al., 2007). Two different datasets are combined in order to produce the biogenic gridded emissions for the model. Emissions from ecosystems are produced by MEGAN (Model of Emissions of Gases and Aerosols from Nature) (Guenther et al., 2006). MEGAN inputs include the leaf area index, the plant functional type and the emission factors while the weather data needed for MEGAN are provided from the WRF model. The sesquiterpene emissions have been set to $30 \%$ of the monoterpene emissions (Helmig et al., 2006). For sea salt emissions the marine aerosol emission model developed by O'Dowd et al. (2008) was used, which uses wind speed data from WRF and chlorophyll $a$ concentrations as inputs for the calculations. In addition, for the summer period we also included emissions data from wildfires (Sofiev et al., 2008a, b). The Saharan dust emissions are not modeled explicitly but are included as boundary conditions in the domain. The dust emissions from Europe are included in the corresponding inventories.

\subsection{Model evaluation}

Fountoukis et al. (2011) evaluated PMCAMx-2008 against high time resolution aerosol mass spectrometer (AMS) ground measurements taken at four European measurement stations (Cabauw, Finokalia, Mace Head and Melpitz), as 
Table 1. Emission mass totals for gaseous and $\mathrm{PM}_{2.5}$ species (in ktons month ${ }^{-1}$ ) for the European domain during the modelled summer and the modelled winter period.

\begin{tabular}{|c|c|c|c|c|c|c|c|c|c|c|c|c|c|}
\hline Species & & $\mathrm{CO}$ & $\mathrm{NO}_{\mathrm{x}}$ & $\mathrm{SO}_{2}$ & $\mathrm{NH}_{3}$ & NMVOC & $\mathrm{NO}_{3}^{-}$ & Sulfate & $\mathrm{NH}_{4}^{+}$ & EC & $\mathrm{OC}$ & $\mathrm{Na}^{+}$ & $\mathrm{Cl}^{-}$ \\
\hline \multirow[t]{2}{*}{ Summer } & Anthropogenic & 3682 & 1461 & 1675 & 501 & 1291 & - & - & - & 47 & 68 & - & - \\
\hline & Biogenic & 1207 & 46 & 3 & 11 & 1872 & 4 & 146 & 1 & 12 & 81 & 512 & 920 \\
\hline \multirow[t]{2}{*}{ Winter } & Anthropogenic & 5002 & 1531 & 1961 & 474 & 1334 & - & - & - & 62 & 112 & - & - \\
\hline & Biogenic & 80 & 5 & 59 & - & 257 & - & 298 & - & - & 12 & 1140 & 2050 \\
\hline
\end{tabular}

well as airborne measurements from an aircraft field campaign over Europe, during May 2008. On a domain-average basis, organic aerosol was predicted to account for $32 \%$ of total $\mathrm{PM}_{1}$ mass at ground level, followed by sulfate (30\%), ammonium (13\%), nitrate (7\%), and elemental carbon $(4 \%)$. The comparison of the model predictions with hourly average ground measurements was encouraging. The monthly average concentrations for $\mathrm{PM}_{1} \mathrm{OA}$, nitrate, sulfate and ammonium, measured in the four stations were 3.3, $1.7,2.8$ and $1.5 \mu \mathrm{g} \mathrm{m}^{-3}$ respectively compared to the predicted average values of $3,2.8,2.9$ and $1.7 \mu \mathrm{g} \mathrm{m}^{-3}$. The model reproduced more than $87 \%$ of the hourly averaged data within a factor of 2 for $\mathrm{PM}_{1} \mathrm{OA}$. The mean bias for OA was $-0.4 \mu \mathrm{g} \mathrm{m}^{-3}$ while the corresponding normalized mean bias (NMB) and normalized mean error (NME) were $11 \%$ (small underprediction) and $30 \%$ respectively. Compared to the daily averaged measurement values, the model performed well for OA reproducing more than $94 \%$ of the hourly data within a factor of 2 . In addition, the model performed well in reproducing the high degree of oxidation as well as the average diurnal profile of the organic concentrations observed in the Eastern Mediterranean region while it tended to predict relatively flat average diurnal profiles for $\mathrm{PM}_{1} \mathrm{OA}$ in many areas, both rural and urban in agreement with observations.

For $\mathrm{PM}_{1}$ sulfate the model performance was also encouraging reproducing more than $70 \%$ of the hourly data points and more than $82 \%$ of the daily averaged data within a factor of 2. Although, the model predictions for sulfate were subject to significant scatter $(\mathrm{NME}=47 \%$, mean error $=1.3$ $\mu \mathrm{g} \mathrm{m}^{-3}$, fractional error $\left.=0.4\right)$. The NMB in Cabauw, Finokalia and Melpitz was $29 \%$ for $\mathrm{PM}_{1}$ nitrate and to $2 \%$ for $\mathrm{PM}_{1}$ ammonium and the corresponding mean biases were 0.4 and $0.03 \mu \mathrm{g} \mathrm{m}^{-3}$ respectively. Potential explanations for the tendency of the model to overpredict ammonium nitrate in these areas include overestimation of the ammonia emissions, uncertainties in the AMS measurements and of course incomplete understanding of the corresponding production and removal processes. The model predicted significantly higher concentrations for both nitrate and ammonium in Mace Head, compared to the measurements. These errors could be partly attributed to the use of the bulk equilibrium approach for the simulation of the inorganic aerosol growth and the fact that a significant amount of nitrate over this area is associated with sea salt, which shifts nitrate and ammonium to the coarse mode (Dall'Osto et al., 2010). Karydis et al. (2010), found a similar behavior for nitrate, in the high dust concentration area of Mexico City where the bulk equilibrium approach of PMCAMx-2008 was unable to capture this effect. Similarly to our results, they underpredicted concentrations of nitrate and ammonium in the coarse mode and overpredicted them in the fine mode. The prediction skill metrics of PMCAMx-2008 against AMS hourly ground measurements during the EUCAARI summer campaign are summarized in Table S1 in the Supplement. The respective skill metrics of the comparison during the EUCAARI winter campaign are summarized in Table S3 (see Supplement).

The model predictions showed that $\mathrm{PM}_{1}$ sulfate concentrations in the Mediterranean region are much higher than the $\mathrm{PM}_{1} \mathrm{OA}$ during the late spring period, while organic matter is predicted to be the dominant $\mathrm{PM}_{1}$ species over a large part of continental Europe. Oxidized POA and OA from intermediate volatility organic compounds (IVOCs) were predicted to be the dominant OA components, contributing around $50 \%$ to total OA, while biogenic SOA comprised on average almost one third of the total predicted OA over the domain. In addition, the model predicted low levels of fresh POA in most areas of the domain, with an exception for urban and suburban areas located mainly in central and Northern Europe. Compared to a positive matrix factorization analysis of the organic aerosol AMS data at Finokalia (Hildebrandt et al., 2010a), PMCAMx-2008 correctly predicted negligible hydrocarbon-like organic aerosol (HOA) concentrations $\left(\sim 0.02 \mu \mathrm{g} \mathrm{m}^{-3}\right)$ as a result of no strong local sources and rapid conversion of POA to OPOA. On average, both AMS and PMCAMx-2008 give high oxygenated organic aerosol concentrations (more than $98 \%$ of total OA in this area). A more detailed comparison between the PMCAMx-2008 predicted concentrations of OA components and the PMF analysis of AMS data from various European sites, during different periods, is in progress and will be presented in a forthcoming paper.

The capability of PMCAMx-2008 to reproduce the vertical distribution of sub-micron aerosol chemical composition was evaluated by comparing the model predictions with the airborne AMS data from 15 flights. The model performance against the high time resolution airborne measurements of 
$\mathrm{OA}$ and sulfate at multiple altitudes and locations was as good as its performance against the ground level hourly measurements. The measured average concentrations for $\mathrm{PM}_{1}$ $\mathrm{OA}$, nitrate, sulfate and ammonium were 2.6, 1.6, 1.6 and $1.2 \mu \mathrm{g} \mathrm{m}^{-3}$ respectively compared to the predicted average values of $2.2,1.4,1.6$ and $1.3 \mu_{\mathrm{g} \mathrm{m}}{ }^{-3}$. However, compared to the ground measurements the scatter in this comparison was a little larger since the model predictions are compared against each one of the AMS measurements (total of $\sim 7000$ points) instead of comparing hourly averages. Overall the model predictions showed small NMB, from $1 \%$ (ammonium) to $-15 \%(\mathrm{OA})$ and larger NME (from $42 \%$ for OA to $69 \%$ for nitrate), while the model correctly predicted more than $66 \%$ and $62 \%$ of the observed concentrations within a factor of 2 for OA and sulfate respectively. Table S2 in the Supplement gives a summary for the statistical metrics of the comparison between the airborne AMS data and PMCAMx2008 predictions.

\section{Simulated periods}

PMCAMx-2008 was used for the simulation of two monthlong periods one during summer and one during the winter. Summer results were based on a hot period (1-29 May 2008) while the winter simulation was based on a cool late winter and early spring period (25 February-23 March 2009). These two periods have been selected to be representative of each season allowing us to reduce the computational cost of the overall effort. Both periods included a variety of meteorological conditions and pollution levels. For example, the first half of May was characterized by a blocking anticyclone leading to stable meteorological conditions and high pollution levels over Central Europe. Hamburger et al. (2011) have provided an extended analysis of the synoptic and pollution situation over Europe during this period. High temperatures were observed in most of northern and southern Europe (Pikridas et al., 2010; Poulain et al., 2011; Mensah et al., 2012), leading to enhanced photochemical activity, which is characteristic of early summer. The winter period was relatively typical with low temperatures observed in most areas of the domain (Hildebrandt et al., 2010b; Freney et al., 2011; Poulain et al., 2011; Mensah et al., 2012).

The predicted base case averaged concentrations for particulate ammonium, nitrate, sulfate, total OA and total $\mathrm{PM}_{2.5}$ mass during the modeled summer and winter periods are shown in Fig. 2. During the summer period the model predicts high nitrate concentrations in Western Europe, with a predicted maximum of $7 \mu \mathrm{g} \mathrm{m}^{-3}$ in South England. In the rest of the domain nitrate is lower, less than $2 \mu \mathrm{g} \mathrm{m}^{-3}$ in most areas. $\mathrm{PM}_{2.5}$ ammonium shows a similar pattern to nitrate in the domain, while elevated ammonium concentrations show strong association with nitrate, evidence of $\mathrm{NH}_{4} \mathrm{NO}_{3}$ formation in the specific area. Additionally, the highest predicted concentrations for fine sulfate are predicted over the Mediter-

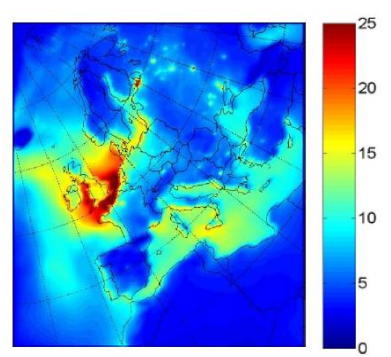

(a) $\mathbf{P M}_{2.5}$ - Summer

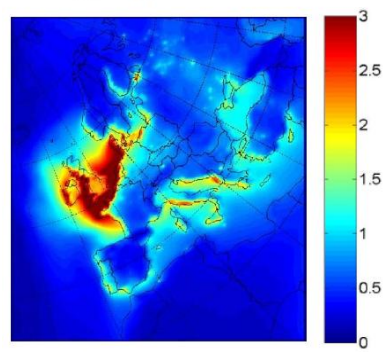

(c) Ammonium - Summer

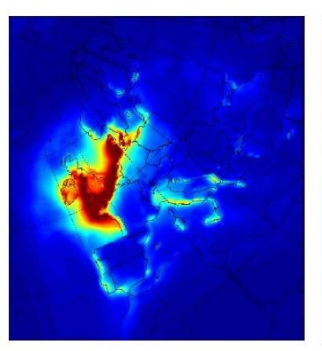

(e) Nitrate - Summer

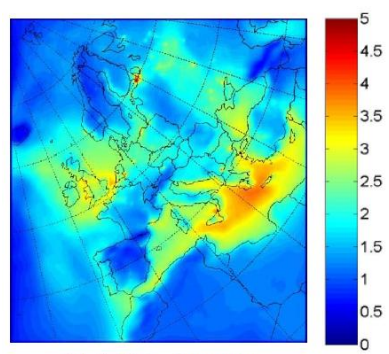

(g) Sulfate - Summer

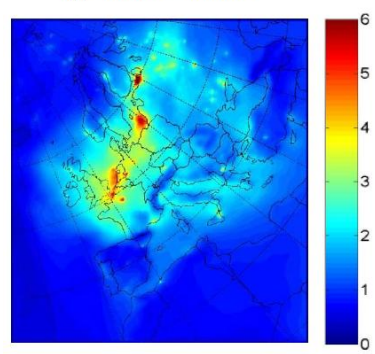

(i) OA - Summer

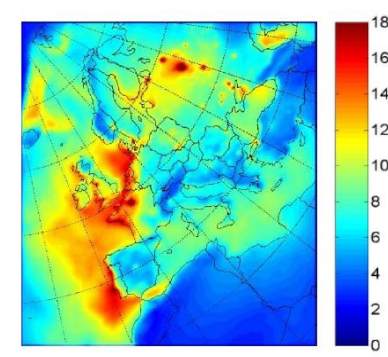

(b) $\mathrm{PM}_{2.5}$ - Winter

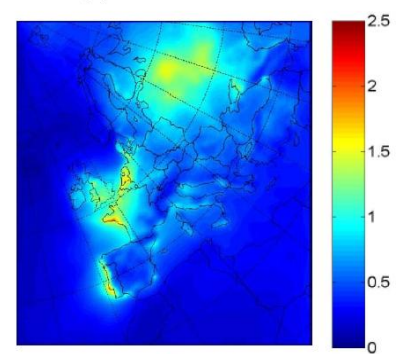

(d) Ammonium - Winter

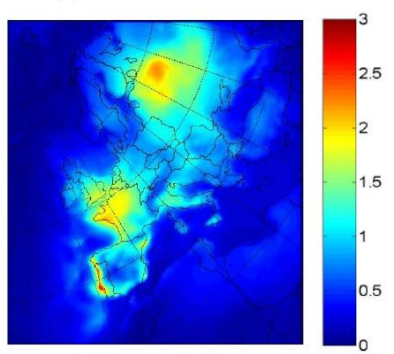

(f) Nitrate - Winter

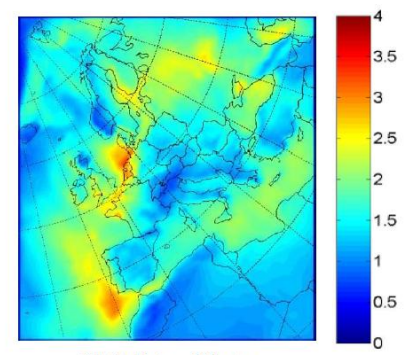

(h) Sulfate - Winter

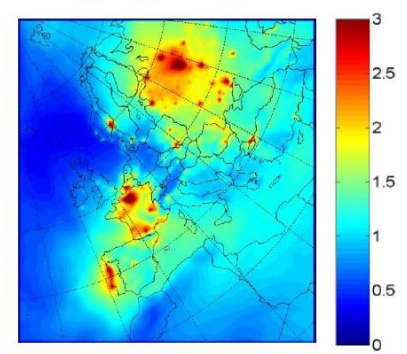

(j) OA - Winter
Fig. 2. Predicted base case ground-level concentrations $\left(\mu \mathrm{g} \mathrm{m}^{-3}\right)$ of (a-b) $\mathrm{PM}_{2.5}$, (c-d) ammonium, (e-f) nitrate, (g-h) sulfate, and $(\mathbf{i}-\mathbf{j})$ total OA, during the modeled summer and the modeled winter period. Different concentration scales are used for each graph. 
ranean while organic matter is predicted to be the dominant $\mathrm{PM}_{2.5}$ component in Central and Northern Europe, with oxidized POA and biogenic SOA contributing around $50 \%$ and $30 \%$ to total OA respectively.

During the winter period, in most areas, the model predicts lower concentrations for nitrate and ammonium with similar spatial trends. Sulfate is predicted to contribute around $20 \%$ of total $\mathrm{PM}_{2.5}$ in a large fraction of the domain, while the highest predicted concentrations for total OA are predicted over Central and North Europe. Fresh POA is predicted to be the dominant $\mathrm{OA}$ component in the winter.

The high levels of total $\mathrm{PM}_{2.5}$ above some sea regions are due to several reasons. During the May period the high PM concentrations in Northern Europe (an area extending from Southern Scandinavia to Western Ireland) were due mainly to high ammonium nitrate concentrations. These predictions are consistent with the extended airborne measurements in the area as well as the measurements in Cabauw and Mace Head (Fountoukis et al., 2011). The high levels over the Mediterranean (central and eastern) were mainly due to high sulfate levels. These higher sulfate levels over the Mediterranean were due to the transport of sulfur dioxide and the resulting sulfates originating from the Balkans and the industrial areas of eastern Europe (Mihalopoulos et al., 1997; Ganor et al., 2000; Lelieveld et al., 2002; Sciare et al., 2003). Dust (in the Mediterranean), sea-salt as well as DMS from phytoplankton also contributed to these elevated levels over water. The elevated levels in the modeled winter period were due to a combination of high ammonium nitrate, organic aerosol and sea-salt.

The model predicts high nitrate concentrations over most of Europe during the modeled winter period and the levels in the Po Valley are relatively high (Fig. 2f). However, this simulated period includes periods of accelerated removal (e.g., high rainfall rates); the concentrations during specific episodes are a lot higher. The model predicts also low OA concentrations over Germany, compared to the available observations in Melpitz. The wintertime underestimation of OA levels was due to the fact that the wood-burning emissions in this area are underestimated. Similar underestimation of the emissions has been found also in Sweden and Switzerland and this will be the topic of a forthcoming publication.

\section{Results}

Five control strategies were examined separately, a $50 \%$ reduction of gaseous emissions $\left(\mathrm{SO}_{2}, \mathrm{NH}_{3}, \mathrm{NO}_{\mathrm{x}}\right.$, anthropogenic VOCs) and a $50 \%$ reduction of anthropogenic primary OA emissions (POA). In the $\mathrm{SO}_{2}, \mathrm{NO}_{\mathrm{x}}$ and $\mathrm{NH}_{3}$ emission control simulations, the initial and boundary conditions of $\mathrm{SO}_{2}, \mathrm{NO}_{\mathrm{x}}$ and $\mathrm{NH}_{3}$ as well as the initial and boundary conditions of sulfate, nitrate, and ammonium were also reduced by $50 \%$. These are oversimplified cases exploring mainly the sensitivity of concentrations to emissions. We fo- cus on the differences between the base case and reduced emission scenario at the ground level.

\subsection{Reduction of $\mathrm{NH}_{3}$ emissions}

The predicted changes in average ground-level concentrations of the major $\mathrm{PM}_{2.5}$ components after a $50 \%$ reduction of $\mathrm{NH}_{3}$ emissions during the modeled summer and the modeled winter period are shown in Fig. 3 and are summarized in Table 2. The reduction of $\mathrm{NH}_{3}$ emissions significantly reduces $\mathrm{PM}_{2.5}$ levels in both periods. The reduction of $\mathrm{PM}_{2.5}$ is mainly attributed to decreases of particulate ammonium nitrate levels. In areas where ammonium nitrate concentration is elevated the effect of $\mathrm{NH}_{3}$ emissions on $\mathrm{PM}_{2.5}$ levels is even higher.

In addition, $\mathrm{NH}_{3}$ control indirectly affects sulfate formation, resulting on a slight decrease of its levels. Sulfate, even in environments with low $\mathrm{NH}_{3}$, exists in the aerosol phase as ammonium sulfate or bisulfate. Part of this sulfate is formed heterogeneously in cloud droplets via the dissolution of gaseous $\mathrm{SO}_{2}$ and its oxidation. The second most important aqueous-phase reaction is the reaction of the dissolved $\mathrm{SO}_{2}$ with $\mathrm{O}_{3}$ at $\mathrm{pH}$ values greater than 5 (Seinfeld and Pandis, 2006). Therefore, the effective cloud $\mathrm{SO}_{2}$ oxidation rate depends partially on the presence of species affecting $\mathrm{pH}$, such as $\mathrm{NH}_{3}$. The respective response of sulfate is mainly due to the reduction of the cloud $\mathrm{pH}$ and the reduction of the rate of in-cloud sulfate production.

During the modeled summer period, total $\mathrm{PM}_{2.5}$ is predicted to decrease by $5.5 \%$ on a domain average basis. The $50 \% \mathrm{NH}_{3}$ reduction is more effective in Western Europe (Fig. 3g) where total $\mathrm{PM}_{2.5}$ is decreased by $2.3 \mu \mathrm{g} \mathrm{m}^{-3}(15 \%)$ on average, with a maximum decrease predicted in South England $\left(5.1 \mu \mathrm{g} \mathrm{m}^{-3}\right.$ or $\left.22.5 \%\right)$. In this area ammonium nitrate levels show the highest reduction $\left(0.73 \mu \mathrm{g} \mathrm{m}^{-3}\right.$ or $35 \%$ and $1.3 \mu \mathrm{g} \mathrm{m}^{-3}$ or $39 \%$ respectively) (Fig. 3a, c) while sulfate decreases by $4 \%$ (Table 2). Significant decreases of $\mathrm{PM}_{2.5}$ levels are also predicted in Southwest $\left(0.75 \mu \mathrm{g} \mathrm{m}^{-3}\right.$ or $10 \%$ on average $)$ and Central Europe $\left(0.8 \mu \mathrm{g} \mathrm{m}^{-3}\right.$ or $9 \%$ on average) while in the rest of the domain the reduction of $\mathrm{PM}_{2.5}$ is lower (Table 2).

During the modeled winter period, the $\mathrm{NH}_{3}$ reduction is also effective in reducing $\mathrm{PM}_{2.5}$ levels (4\% average). Significant decreases of $\mathrm{PM}_{2.5}$ are predicted in Central Europe (up to $1.5 \mu \mathrm{g} \mathrm{m}^{-3}$ or $10 \%$ in northern France) (Fig. 3h), while the average reduction of $\mathrm{PM}_{2.5}$ in this area reaches $0.7 \mu \mathrm{g} \mathrm{m}^{-3}$ (7.5\%). The reduction of inorganic $\mathrm{PM}_{2.5}$ components exceeds $10 \%$ in this area with particulate ammonium and nitrate predicted to decrease by $30 \%$ and $18 \%$ respectively, and $\mathrm{PM}_{2.5}$ sulfate by $11 \%$. In other areas of the domain, total $\mathrm{PM}_{2.5}$ is also predicted to decrease and its reduction ranges from $0.37 \mu \mathrm{g} \mathrm{m}^{-3}(4.5 \%)$ in Western Europe to $0.6 \mu \mathrm{g} \mathrm{m}^{-3}$ $(7 \%)$ in North Europe. 
Table 2. Average predicted concentration reduction and percent average reduction of the major $\mathrm{PM}_{2.5}$ components to a $50 \%$ reduction of $\mathrm{NH}_{3}, \mathrm{NO}_{\mathrm{x}}, \mathrm{SO}_{2}$, VOCs and POA emissions, during the modelled summer and the modelled winter period.

\begin{tabular}{|c|c|c|c|c|c|c|}
\hline \multirow[t]{2}{*}{ Region } & \multirow[t]{2}{*}{$\mathrm{PM}_{2.5}$ Components } & \multicolumn{5}{|c|}{ Control Strategy } \\
\hline & & $-50 \% \mathrm{NH}_{3}$ & $-50 \% \mathrm{NO}_{\mathrm{x}}$ & $-50 \% \mathrm{SO}_{2}$ & $-50 \%$ VOCs & $-50 \%$ POA \\
\hline & & \multicolumn{5}{|c|}{ Predicted Change - Summer } \\
\hline \multirow[t]{5}{*}{$\mathrm{I}^{\mathrm{a}}$} & Ammonium & $0.12(18 \%)^{\mathrm{b}}$ & $0.07(10 \%)$ & $0.08(13 \%)$ & $-0.01(-1.5 \%)$ & $<-0.001(-0.01 \%)$ \\
\hline & Sulfate & $0.04(2 \%)$ & $0.05(3 \%)$ & $0.36(22 \%)$ & $-0.02(-1 \%)$ & $<-0.001(-0.05 \%)$ \\
\hline & Nitrate & $0.12(24 \%)$ & $0.21(44 \%)$ & $-0.04(-8.5 \%)$ & $-0.01(-2.5 \%)$ & $<-0.001(-0.01 \%)$ \\
\hline & $\mathrm{OA}$ & $-0.001(-0.1 \%)$ & $0.07(4 \%)$ & $0.001(0.07 \%)$ & $0.08(5 \%)$ & $0.17(10 \%)$ \\
\hline & Total $\mathrm{PM}_{2.5}$ & $0.3(4.5 \%)$ & $0.38(5.5 \%)$ & $0.4(6 \%)$ & $0.04(0.6 \%)$ & $0.17(2.5 \%)$ \\
\hline \multirow[t]{5}{*}{ II } & Ammonium & $0.73(35 \%)$ & $0.29(13.5 \%)$ & $0.08(3.5 \%)$ & $0.001(0.05 \%)$ & $<-0.001(-0.01 \%)$ \\
\hline & Sulfate & $0.13(5 \%)$ & $-0.13(-5 \%)$ & $0.61(24 \%)$ & $-0.01(-0.5 \%)$ & $<-0.001(-0.01 \%)$ \\
\hline & Nitrate & $1.3(39 \%)$ & $1.25(38 \%)$ & $-0.17(-5 \%)$ & $0.01(0.3 \%)$ & $-0.004(-0.1 \%)$ \\
\hline & $\mathrm{OA}$ & $0.002(0.1 \%)$ & $-0.15(-6 \%)$ & $0.002(0.1 \%)$ & $0.2(9 \%)$ & $0.26(11 \%)$ \\
\hline & Total $\mathrm{PM}_{2.5}$ & $2.3(15 \%)$ & $1.24(8 \%)$ & $0.5(3 \%)$ & $0.2(1.1 \%)$ & $0.26(1.5 \%)$ \\
\hline \multirow[t]{5}{*}{ III } & Ammonium & $0.22(20 \%)$ & $0.23(22 \%)$ & $0.13(13 \%)$ & $-0.02(-2 \%)$ & $0.00(0 \%)$ \\
\hline & Sulfate & $0.12(6.5 \%)$ & $0.03(2 \%)$ & $0.54(30 \%)$ & $-0.02(-1 \%)$ & $0.00(0 \%)$ \\
\hline & Nitrate & $0.43(28 \%)$ & $0.75(49 \%)$ & $-0.12(-7.5 \%)$ & $-0.04(-3 \%)$ & $<-0.001(-0.05 \%)$ \\
\hline & $\mathrm{OA}$ & $-0.002(-0.1 \%)$ & $0.08(3.5 \%)$ & $0.001(0.08 \%)$ & $0.2(9 \%)$ & $0.24(10 \%)$ \\
\hline & Total $\mathrm{PM}_{2.5}$ & $0.8(9 \%)$ & $1.1(12 \%)$ & $0.55(6 \%)$ & $0.1(1.1 \%)$ & $0.24(2.5 \%)$ \\
\hline \multirow[t]{5}{*}{ IV } & Ammonium & $0.26(28 \%)$ & $0.1(10 \%)$ & $0.14(0.16 \%)$ & $-0.01(-1.5 \%)$ & $0.00(0 \%)$ \\
\hline & Sulfate & $0.08(3 \%)$ & $0.2(8 \%)$ & $0.84(34 \%)$ & $-0.05(-2 \%)$ & $<-0.001(-0.02 \%)$ \\
\hline & Nitrate & $0.1(22 \%)$ & $0.2(43 \%)$ & $-0.13(-29 \%)$ & $-0.02(-4 \%)$ & $<0.001(0.01 \%)$ \\
\hline & $\mathrm{OA}$ & $-0.002(-0.1 \%)$ & $0.1(5.5 \%)$ & $0.002(0.1 \%)$ & $0.14(8 \%)$ & $0.1(6 \%)$ \\
\hline & Total $\mathrm{PM}_{2.5}$ & $0.51(6 \%)$ & $0.6(7 \%)$ & $0.8(10 \%)$ & $0.06(0.7 \%)$ & $0.1(1.1 \%)$ \\
\hline \multirow[t]{6}{*}{$\mathrm{V}$} & Ammonium & $0.29(30 \%)$ & $0.1(10.5 \%)$ & $0.06(6 \%)$ & $-0.01(-1 \%)$ & $<0.001(0.02 \%)$ \\
\hline & Sulfate & $0.06(3 \%)$ & $0.03(1.5 \%)$ & $0.54(28 \%)$ & $-0.02(-1 \%)$ & $<-0.001(-0.01 \%)$ \\
\hline & Nitrate & $0.33(32 \%)$ & $0.4(40 \%)$ & $-0.19(-18 \%)$ & $-0.02(-1.5 \%)$ & $<-0.001(-0.07 \%)$ \\
\hline & $\mathrm{OA}$ & $-0.001(-0.06 \%)$ & $0.03(2.5 \%)$ & $0.002(0.1 \%)$ & $0.1(7.5 \%)$ & $0.1(7.5 \%)$ \\
\hline & Total $\mathrm{PM}_{2.5}$ & $0.75(10 \%)$ & $0.53(6.5 \%)$ & $0.38(5 \%)$ & $0.06(0.7 \%)$ & $0.1(1.3 \%)$ \\
\hline & & \multicolumn{5}{|c|}{ Predicted Change - Winter } \\
\hline \multirow[t]{5}{*}{$\mathrm{I}^{\mathrm{a}}$} & Ammonium & $0.19(27 \%)^{\mathrm{b}}$ & $0.03(3.5 \%)$ & $0.04(4.5 \%)$ & $0.01(1.2 \%)$ & $<-0.001(-0.01 \%)$ \\
\hline & Sulfate & $0.13(7.5 \%)$ & $-0.18(-10 \%)$ & $0.26(15 \%)$ & $0.01(0.5 \%)$ & $0.002(0.1 \%)$ \\
\hline & Nitrate & $0.22(25 \%)$ & $0.3(34 \%)$ & $-0.05(-6 \%)$ & $0.04(4 \%)$ & $-0.002(-0.2 \%)$ \\
\hline & $\mathrm{OA}$ & $0.002(0.1 \%)$ & $-0.21(-11 \%)$ & $<0.001(0.05 \%)$ & $0.07(4 \%)$ & $0.3(18 \%)$ \\
\hline & Total $\mathrm{PM}_{2.5}$ & $0.6(7 \%)$ & $-0.03(-0.3 \%)$ & $0.25(3 \%)$ & $0.11(1.3 \%)$ & $0.3(3.5 \%)$ \\
\hline \multirow[t]{5}{*}{ II } & Ammonium & $0.21(35 \%)$ & $-0.002(-0.3 \%)$ & $0.02(3.5 \%)$ & $0.005(0.8 \%)$ & $<-0.001(0.1 \%)$ \\
\hline & Sulfate & $0.08(4 \%)$ & $-0.1(-5 \%)$ & $0.25(12.5 \%)$ & $-0.005(-0.2 \%)$ & $0.001(0.05 \%)$ \\
\hline & Nitrate & $0.11(15 \%)$ & $0.11(16 \%)$ & $0.02(3 \%)$ & $0.03(4.5 \%)$ & $-0.002(-0.3 \%)$ \\
\hline & $\mathrm{OA}$ & $0.001(0.15 \%)$ & $-0.1(-13 \%)$ & $<0.001(0.05 \%)$ & $0.01(2 \%)$ & $0.14(19 \%)$ \\
\hline & Total $\mathrm{PM}_{2.5}$ & $0.5(4.5 \%)$ & $-0.08(-0.7 \%)$ & $0.29(2.5 \%)$ & $0.04(0.3 \%)$ & $0.14(1.1 \%)$ \\
\hline \multirow[t]{5}{*}{ III } & Ammonium & $0.22(30 \%)$ & $0.03(4.5 \%)$ & $0.04(5.5 \%)$ & $0.007(1 \%)$ & $-0.001(-0.1 \%)$ \\
\hline & Sulfate & $0.17(11 \%)$ & $-0.15(-9 \%)$ & $0.25(15 \%)$ & $-0.001(-0.05 \%)$ & $0.002(0.1 \%)$ \\
\hline & Nitrate & $0.2(18 \%)$ & $0.29(26 \%)$ & $-0.02(-1.6 \%)$ & $0.04(3.5 \%)$ & $-0.003(-0.2 \%)$ \\
\hline & $\mathrm{OA}$ & $<0.001(0.07 \%)$ & $-0.18(-14 \%)$ & $<0.001(0.01 \%)$ & $0.04(3 \%)$ & $0.35(25 \%)$ \\
\hline & Total $\mathrm{PM}_{2.5}$ & $0.67(7.5 \%)$ & $-0.02(-0.2 \%)$ & $0.27(3 \%)$ & $0.08(0.9 \%)$ & $0.36(4 \%)$ \\
\hline \multirow[t]{5}{*}{ IV } & Ammonium & $0.14(29 \%)$ & $0.02(4 \%)$ & $0.02(4 \%)$ & $0.002(0.4 \%)$ & $-0.001(-0.2 \%)$ \\
\hline & Sulfate & $0.06(4 \%)$ & $-0.14(-9 \%)$ & $0.27(18 \%)$ & $0.003(0.2 \%)$ & $<-0.001(-0.02 \%)$ \\
\hline & Nitrate & $0.13(22 \%)$ & $0.22(36 \%)$ & $-0.05(-8 \%)$ & $0.01(1.5 \%)$ & $-0.001(-0.2 \%)$ \\
\hline & $\mathrm{OA}$ & $<0.001(0.02 \%)$ & $-0.15(-10 \%)$ & $<0.001(0.04 \%)$ & $0.06(5 \%)$ & $0.16(14 \%)$ \\
\hline & Total $\mathrm{PM}_{2.5}$ & $0.37(5.5 \%)$ & $-0.05(-0.7 \%)$ & $0.23(3.3 \%)$ & $0.07(1 \%)$ & $0.16(2.3 \%)$ \\
\hline \multirow[t]{5}{*}{ V } & Ammonium & $0.18(30 \%)$ & $0.03(4.5 \%)$ & $0.02(2.5 \%)$ & $<-0.001(-0.06 \%)$ & $-0.001(-0.1 \%)$ \\
\hline & Sulfate & $0.03(2 \%)$ & $-0.1(-6 \%)$ & $0.29(18 \%)$ & $-0.002(-0.1 \%)$ & $<-0.001(-0.002 \%)$ \\
\hline & Nitrate & $0.23(29 \%)$ & $0.24(30 \%)$ & $-0.1(-12.5 \%)$ & $0.003(0.3 \%)$ & $-0.002(-0.2 \%)$ \\
\hline & $\mathrm{OA}$ & $<0.001(0.04 \%)$ & $-0.13(-10 \%)$ & $<0.001(0.04 \%)$ & $0.06(4.5 \%)$ & $0.14(10 \%)$ \\
\hline & Total $\mathrm{PM}_{2.5}$ & $0.5(6 \%)$ & $0.02(0.2 \%)$ & $0.18(2.2 \%)$ & $0.06(0.7 \%)$ & $0.14(2 \%)$ \\
\hline
\end{tabular}

a The location of the five regions used for the analysis is shown in Fig. 1.

b A positive value corresponds to a decrease. 


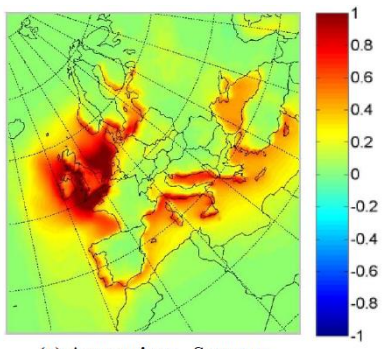

(a) Ammonium - Summer

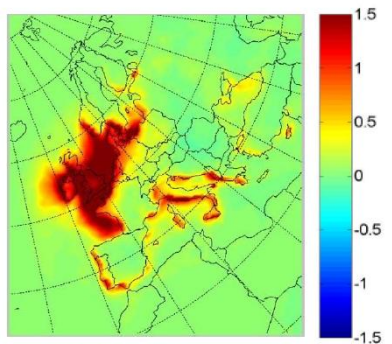

(c) Nitrate - Summer

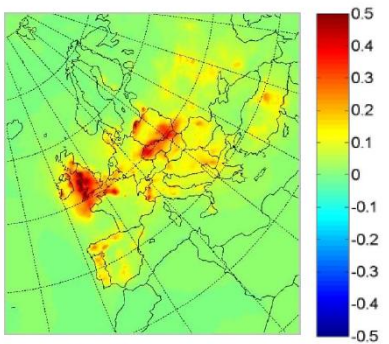

(e) Sulfate-Summer

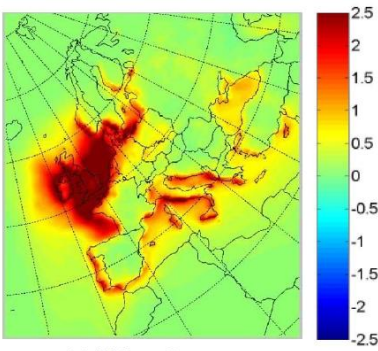

(g) $\mathrm{PM}_{2.5}$ - Summer

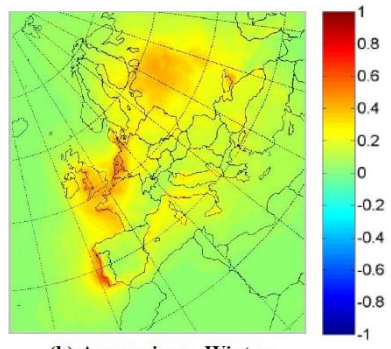

(b) Ammonium - Winter

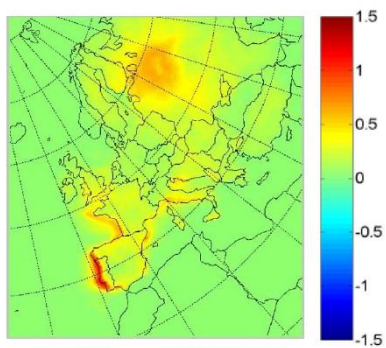

(d) Nitrate - Winter

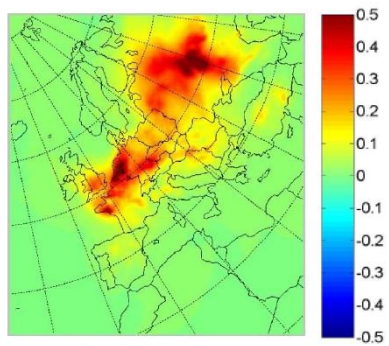

(f) Sulfate - Winter

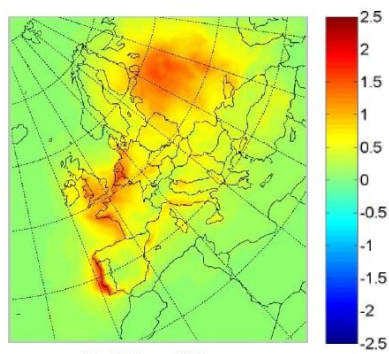

(h) $\mathrm{PM}_{2.5}$ - Winter

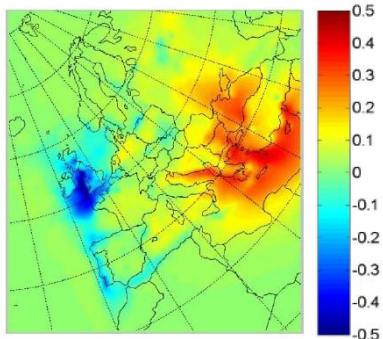

(a) Sulfate-Summer

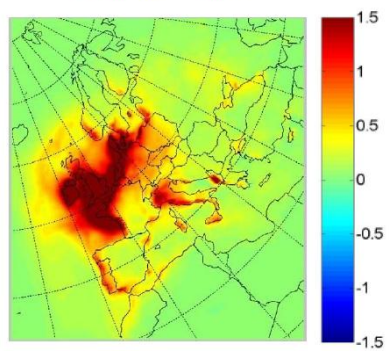

(c) Nitrate - Summer

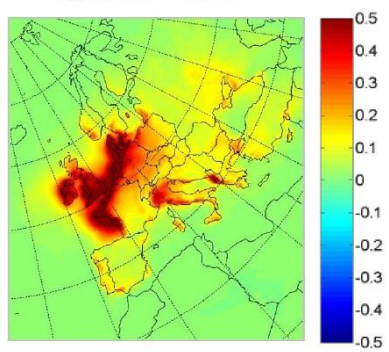

(e) Ammonium - Summer

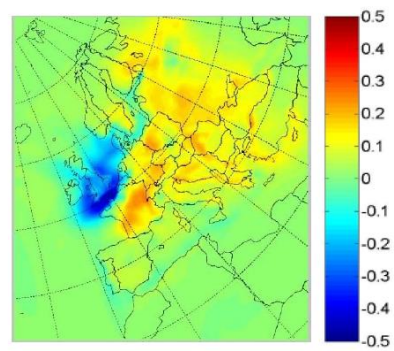

(g) $\mathrm{OA}$ - Summer

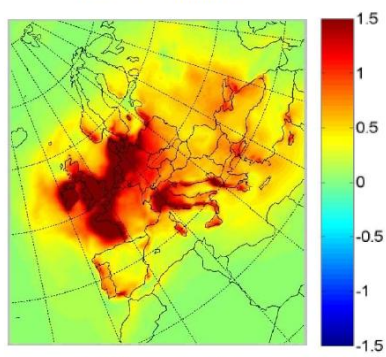

(i) $\mathrm{PM}_{2,5}$ - Summer

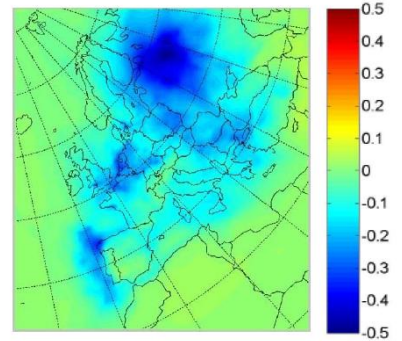

(b) Sulfate - Winter

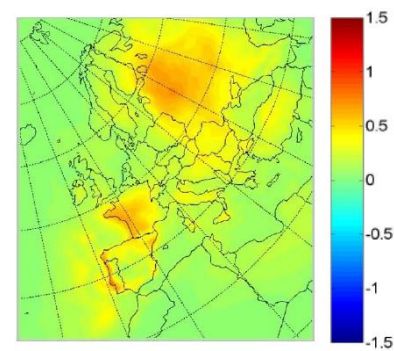

(d) Nitrate - Winter

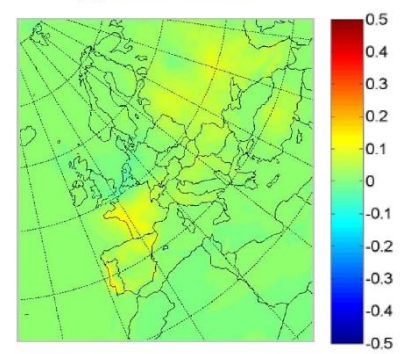

(f) Ammonium - Winter

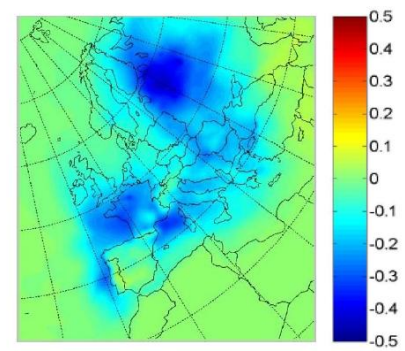

(h) OA - Winter

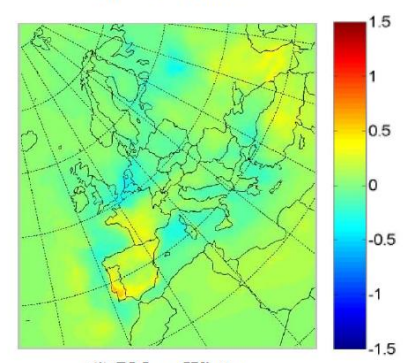

(j) $\mathbf{P M}_{2,5}$ - Winter

During the modeled summer period, the reduction of $\mathrm{NO}_{\mathrm{x}}$ emissions by $50 \%$ results in a net decrease of total $\mathrm{PM}_{2.5}$ levels over Europe (5.5\% on average). However, its effect on the individual $\mathrm{PM}_{2.5}$ components is quite variable spatially. Although the $\mathrm{NO}_{\mathrm{x}}$ reduction results in significant decreases of ammonium nitrate levels in the entire domain (Fig. 4c, e) the response of sulfate and total $\mathrm{OA}$ to $\mathrm{NO}_{\mathrm{x}}$ emissions changes differs, depending on the respective changes of $\mathrm{OH}$ and $\mathrm{O}_{3}$.

Fig. 4. Predicted reduction (base case - emissions reduction scenario) in ground-level concentrations $\left(\mu \mathrm{g} \mathrm{m}^{-3}\right)$ of $(\mathbf{a}-\mathbf{b})$ sulfate, $(\mathbf{c}-$ d) nitrate, $(\mathbf{e}-\mathbf{f})$ ammonium, $(\mathbf{g}-\mathbf{h})$ total $\mathrm{OA}$, and (i-j) total $\mathrm{PM}_{2.5}$ after a $50 \%$ reduction of $\mathrm{NO}_{\mathrm{x}}$ emissions during the modeled summer and the modeled winter period. A positive value corresponds to a decrease. 
The main source of sulfate is the oxidation of $\mathrm{SO}_{2}$, which takes place either homogeneously (reaction with $\mathrm{OH}$ ) or heterogeneously (cloud reactions with dissolved hydrogen peroxide or ozone) (Pandis and Seinfeld, 1989). Thus, the levels of $\mathrm{OH}$ are critical for the formation of sulfate. Under typical polluted conditions, $\mathrm{OH}$ reacts with $\mathrm{VOCs}$ and $\mathrm{NO}_{2}$ at an equal rate when the $\mathrm{VOC} / \mathrm{NO}_{\mathrm{x}}$ concentration ratio is approximately $5.5: 1$ (Seinfeld and Pandis, 2006). In areas where the $\mathrm{VOC} / \mathrm{NO}_{\mathrm{x}}$ ratio is higher than this value, $\mathrm{OH}$ preferentially reacts with VOCs. In these $\mathrm{NO}_{\mathrm{x}}$-limited areas, a reduction of $\mathrm{NO}_{\mathrm{x}}$ levels decreases the rate of $\mathrm{O}_{3}$ formation, leading to lower $\mathrm{OH}$ radical concentration. As a result, a reduction of $\mathrm{NO}_{\mathrm{x}}$ emissions, by reducing $\mathrm{OH}$, can indirectly decrease sulfate concentration levels (Stockwell and Calvert, 1983). On the contrary at a lower ratio of $\mathrm{VOC}$ to $\mathrm{NO}_{\mathrm{x}}$ concentration, the $\mathrm{NO}_{\mathrm{x}}$ reaction predominates. In these $\mathrm{NO}_{\mathrm{x}}$-saturated areas, a reduction of $\mathrm{NO}_{\mathrm{x}}$ emissions results in an increase of $\mathrm{OH}$ and $\mathrm{O}_{3}$ and subsequently sulfate concentrations can increase. Figure $\mathrm{S} 1$ in the Supplement shows the predicted base case $\mathrm{VOC} / \mathrm{NO}_{\mathrm{x}}$ ratio for each simulation period and the corresponding changes to $\mathrm{VOC} / \mathrm{NO}_{\mathrm{x}}$ ratio after the reduction of $\mathrm{NO}_{\mathrm{x}}$ and VOCs emissions. The reduction of $\mathrm{NO}_{\mathrm{x}}$ emissions also impacts the oxidant levels and consequently affects POA aging as well as anthropogenic and biogenic SOA formation.

The lower $\mathrm{NO}_{\mathrm{x}}$ in the summer period has a significant effect on total $\mathrm{PM}_{2.5}$ levels in Central Europe, reducing them by $1.1 \mu \mathrm{g} \mathrm{m}^{-3}(12 \%)$ (Fig. $4 \mathrm{i}$ ). This reduction is mainly due to the significant decrease of nitrate $\left(0.75 \mu \mathrm{g} \mathrm{m}^{-3}\right.$ or $\left.49 \%\right)$, as the reduction of $\mathrm{NO}_{\mathrm{x}}$ leads to a decrease of oxidant levels in this area (the VOC to $\mathrm{NO}_{\mathrm{x}}$ concentration ratio is higher than $5.5: 1$ threshold value), and eventually less $\mathrm{HNO}_{3}$ is formed, as well as to a decrease of ammonium (18\% on average). A slight decrease of sulfate and total OA which is mainly attributed to reductions of oxidized POA and the corresponding SOA from intermediate volatile organic compounds (IVOCs) (account for $50 \%$ of OA decrease) contribute also to the net decrease of total $\mathrm{PM}_{2.5}$ in Central Europe. The $\mathrm{NO}_{\mathrm{x}}$ control has a significant effect on total $\mathrm{PM}_{2.5}$ levels in Western Europe, reducing them by $1.24 \mu \mathrm{g} \mathrm{m}^{-3}(8 \%)$ due to a reduction of nitrate and ammonium by $38 \%$ and $13.5 \%$ respectively. Over Western Europe the VOC to $\mathrm{NO}_{\mathrm{x}}$ ratio is lower than the 5.5: 1 limit. Therefore, in this $\mathrm{NO}_{\mathrm{x}}$-saturated region, the $50 \% \mathrm{NO}_{\mathrm{x}}$ reduction leads to an increase of oxidant levels and consequently to an increase of sulfate and total OA levels (Table 2).

In the modeled winter period, the reduction of $\mathrm{NO}_{\mathrm{x}}$ emissions is also effective for reducing nitrate levels over Europe. Nitrate is predicted to decrease everywhere $(30 \%$ on average), with its reduction being more significant in North $\mathrm{Eu}-$ rope (Table 2). However, during wintertime the VOC to $\mathrm{NO}_{\mathrm{x}}$ ratio is lower than $5.5: 1$ in most of the model domain (see Fig. S1 in the Supplement) due to lower biogenic emissions, thus the $\mathrm{NO}_{\mathrm{x}}$ control results in an increase of the oxidant levels. The increase of oxidant levels increases sulfate concentration in most areas over Europe (Fig. 4b), with a highest

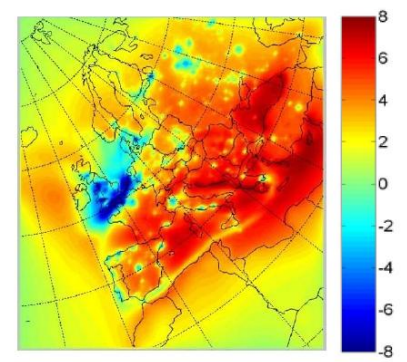

(a) $\mathrm{O}_{3}$ - Summer

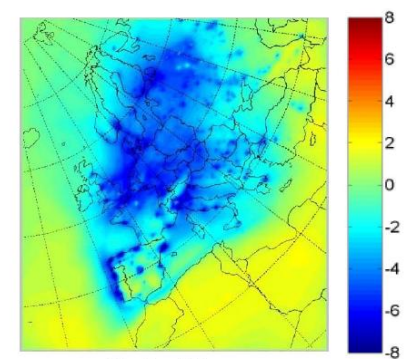

(b) $\mathbf{O}_{3}$ - Winter
Fig. 5. Predicted reduction (base case - emissions reduction scenario) in ground-level concentrations (ppb) of $\mathrm{O}_{3}$ after a $50 \%$ reduction of $\mathrm{NO}_{\mathrm{x}}$ emissions during (a) the modeled summer period and (b) the modeled winter period. A positive value corresponds to a decrease.

increase predicted in North and Central Europe (10\% and $9 \%$ respectively). Additionally, the increase of oxidant levels accelerates the oxidation of OA precursors leading also to higher oxidized POA and SOA levels. In areas were OA is high (North, Central Europe), $\mathrm{NO}_{\mathrm{x}}$ control is predicted to have the highest effect, increasing OA by $11 \%$ and $13 \%$ respectively. In most areas of the domain, the predicted increases of sulfate and total OA levels are usually higher than the nitrate decreases resulting to a net increase of total $\mathrm{PM}_{2.5}$ (Table 2).

The predicted $\mathrm{O}_{3}$ response to the decreasing $\mathrm{NO}_{\mathrm{x}}$ was found to vary in time and space (based on the VOC to $\mathrm{NO}_{\mathrm{x}}$ ratio). During the modeled summer period, the $\mathrm{NO}_{\mathrm{x}}$ reduction leads to a decrease of ozone amounts in most of the model domain (Fig. 5a), with the highest reduction predicted in the Balkans (14\% on average). In Southwest Europe $\mathrm{O}_{3}$ is reduced by $9 \%$ while similar decreases are predicted in Central and North Europe (8\% on average). However in major urban areas such as Paris, London, Madrid and Milan the response of $\mathrm{O}_{3}$ differs. In these $\mathrm{NO}_{\mathrm{x}}$-saturated areas, $\mathrm{O}_{3}$ is predicted to increase by several ppb (up to $8 \mathrm{ppb}$ or $43 \%$ in London). Increase of $\mathrm{O}_{3}$ concentration is predicted also in Western Europe (4\% on average). During the modeled winter period, $\mathrm{O}_{3}$ is predicted to increase in most areas of the domain, after the $50 \%$ reduction of $\mathrm{NO}_{\mathrm{x}}$ emissions (Fig. 5b). The predicted increase of $\mathrm{O}_{3}$ exceeds $10 \%$ especially over Central and North Europe where average $\mathrm{O}_{3}$ increased by $4.2 \mathrm{ppb}(26 \%)$ and $3 \mathrm{ppb}(17 \%)$ respectively.

\subsection{Reduction of $\mathrm{SO}_{2}$ emissions}

The predicted changes in average ground-level concentrations of the major $\mathrm{PM}_{2.5}$ components after a $50 \%$ reduction of $\mathrm{SO}_{2}$ emissions during the modeled summer and winter periods are shown in Fig. 6 and are summarized in Table 2. The reduction of $\mathrm{SO}_{2}$ emissions is predicted to have different impacts on the different inorganic $\mathrm{PM}_{2.5}$ components. Sulfate levels are effectively reduced over Europe in both periods, 


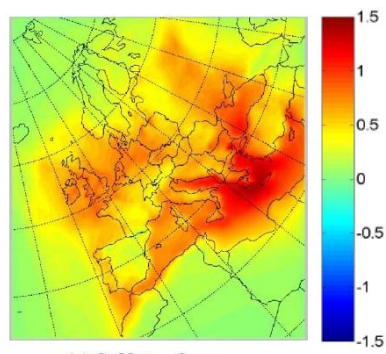

(a) Sulfate - Summer

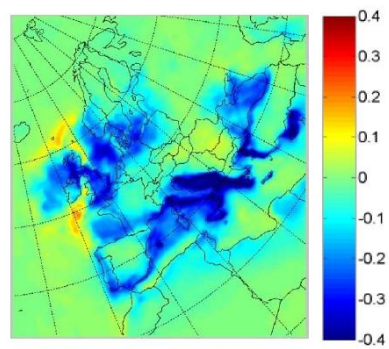

(c) Nitrate - Summer

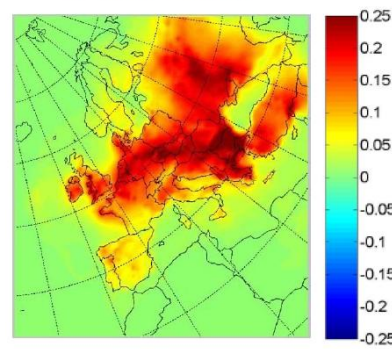

(e) Ammonium - Summer

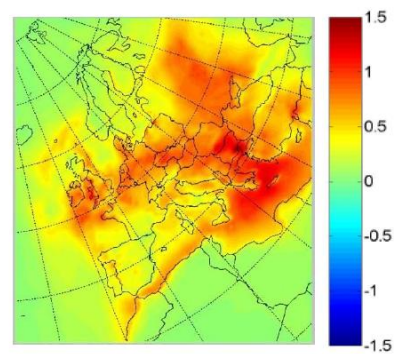

(g) $\mathbf{P M}_{2.5}$ - Summer

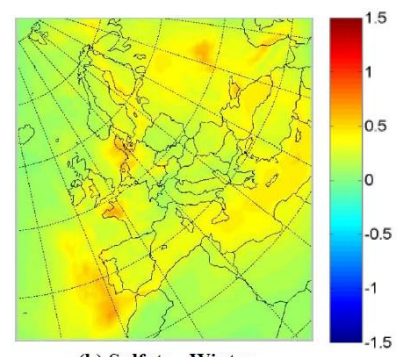

(b) Sulfate - Winter

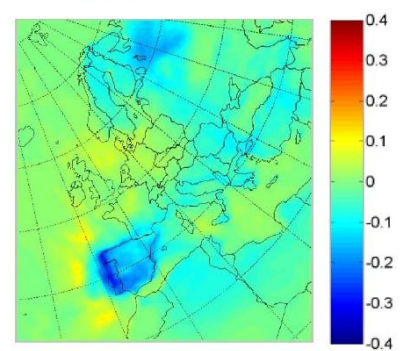

(d) Nitrate - Winter

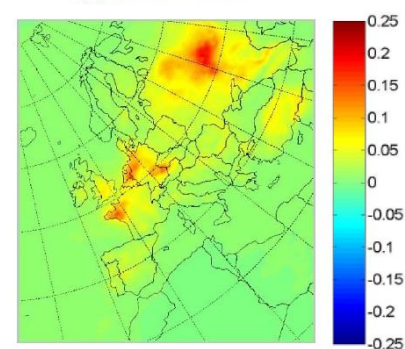

(f) Ammonium - Winter

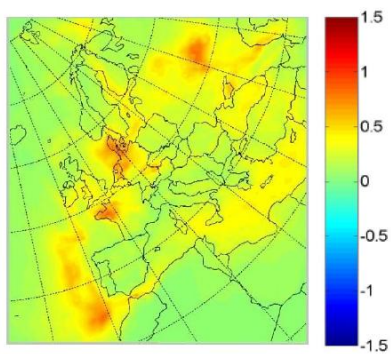

(h) $\mathrm{PM}_{2.5}$ - Winter
Fig. 6. Predicted reduction (base case - emissions reduction scenario) in ground-level concentrations $\left(\mu \mathrm{g} \mathrm{m}^{-3}\right)$ of $(\mathbf{a}-\mathbf{b})$ sulfate, $(\mathbf{c}-$ d) nitrate, (e-f) ammonium, and (g-h) total $\mathrm{PM}_{2.5}$ after a $50 \%$ reduction of $\mathrm{SO}_{2}$ emissions during the modeled summer and the modeled winter period. A positive value corresponds to a decrease.

while the $\mathrm{SO}_{2}$ reduction also causes decreases in particulate ammonium (Table 2).

On the contrary the response of nitrate to $\mathrm{SO}_{2}$ reduction is variable depending on the availability of free $\mathrm{NH}_{3}$ and total nitrate in each area. $\mathrm{NH}_{3}$ reacts preferentially with $\mathrm{H}_{2} \mathrm{SO}_{4}$, and, if sufficient $\mathrm{NH}_{3}$ is available (free $\mathrm{NH}_{3}$ ), it also reacts with $\mathrm{HNO}_{3}$ forming particulate nitrate. Thus, a reduction of $\mathrm{SO}_{2}$ can lead to an increase of free $\mathrm{NH}_{3}$ and consequently more $\mathrm{HNO}_{3}$ can be transferred to the particulate phase (electroneutrality effect) (Seinfeld and Pandis, 2006). However the formation of $\mathrm{NH}_{4} \mathrm{NO}_{3}$ depends on its equilibrium vapour pressure product of ammonia and nitric acid, $\mathrm{K}_{\mathrm{AN}}$, which in general, depends on temperature, $\mathrm{RH}$ and sulfate concentration (Stelson and Seinfeld, 1986). In the aqueous particulate phase, when sulfate increases, $K_{\mathrm{AN}}$ decreases due to ion interactions. Consequently the reduction of sulfate levels increases $K_{\mathrm{AN}}$, which may cause a decrease of ammonium nitrate (thermodynamic effect) (Ansari and Pandis, 1998). In areas where the total nitrate is high and the $\mathrm{NH}_{3}$ is low, nitrate tends to increase because of the electroneutrality effect, while in areas with high free $\mathrm{NH}_{3}$, nitrate tends to decrease due to the thermodynamic effect.

During the modeled summer period the $50 \%$ reduction of $\mathrm{SO}_{2}$ emissions produces an average sulfate decrease of $23 \%$ in the entire domain (Fig. 6a). The $\mathrm{SO}_{2}$ control strategy is more effective in the Balkans where sulfate is reduced by $0.84 \mu \mathrm{g} \mathrm{m}^{-3}$ (34\%) on average, while its reduction reaches up to $1.4 \mu \mathrm{g} \mathrm{m}^{-3}(37 \%)$ in the Eastern Mediterranean whereas sulfate has the highest concentration. In the other areas, the predicted sulfate decrease is also significant (Table 2) indicating that $\mathrm{SO}_{2}$ is often the limiting reagent for sulfate formation during summer. $\mathrm{SO}_{2}$ control has also a significant impact on nitrate levels, resulting in an increase of its concentration in most areas of the domain $(16 \%$ on average) (Fig. 6c), with the highest increase predicted over the Balkans $\left(0.13 \mu \mathrm{g} \mathrm{m}^{-3}\right.$ or $29 \%$ on average). However, despite the increase of nitrate, the predicted reduction of sulfate after the $\mathrm{SO}_{2}$ control is higher, and along with the decrease of ammonium (up to $16 \%$ in the Balkans) results in a net decrease of total $\mathrm{PM}_{2.5}$ levels (Fig. $6 \mathrm{~g}$ ) which is ranging from $0.38 \mu \mathrm{g} \mathrm{m}^{-3}(5 \%)$ in Southwest Europe to $0.8 \mu \mathrm{g} \mathrm{m}^{-3}(10 \%)$ in the Balkans.

In the modeled winter period, the $\mathrm{SO}_{2}$ reduction is also effective in reducing sulfate in most areas of the domain (Table 2). However the response of sulfate to $\mathrm{SO}_{2}$ reductions (an approximate reduction of $0.25 \mu \mathrm{g} \mathrm{m}^{-3}$ ) is lower compared to summertime, as the in-cloud formation of sulfate by the reaction of dissolved $\mathrm{SO}_{2}$ with $\mathrm{H}_{2} \mathrm{O}_{2}$ is often limited by $\mathrm{H}_{2} \mathrm{O}_{2}$ availability during winter. Similar to summertime, nitrate levels are also predicted to increase after the reduction of $\mathrm{SO}_{2}$ emissions, with the highest increase predicted in Southwest Europe $\left(0.1 \mu \mathrm{g} \mathrm{m}^{-3}\right.$ or $\left.12.5 \%\right)$. Nevertheless, the predicted increases of nitrate are once more less than sulfate decreases. Thus, the net impact on $\mathrm{PM}_{2.5}$ is a $2-2.5 \%$ reduction.

\subsection{Reduction of anthropogenic VOCs emissions}

When the emissions of VOCs are halved, the oxidant levels $\left(\mathrm{O}_{3}, \mathrm{OH}\right)$ either increase $\left(\mathrm{NO}_{\mathrm{x}}\right.$-limited areas) or decrease $\left(\mathrm{NO}_{\mathrm{x}}\right.$-saturated areas). This variable response, as we have seen, is determined by the $\mathrm{VOC} / \mathrm{NO}_{\mathrm{x}}$ ratio and is the key for understanding the response of $\mathrm{PM}_{2.5}$ components after this reduction. For example, the reduction of anthropogenic VOCs is expected to reduce total OA levels, although in 


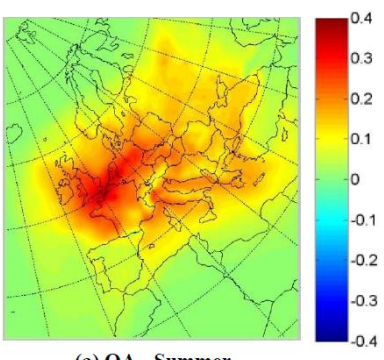

(a) $\mathrm{OA}$ - Summer

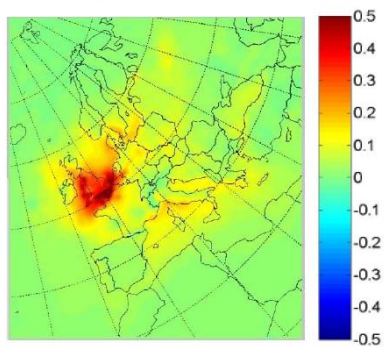

(c) $\mathrm{PM}_{2.5}$ - Summer

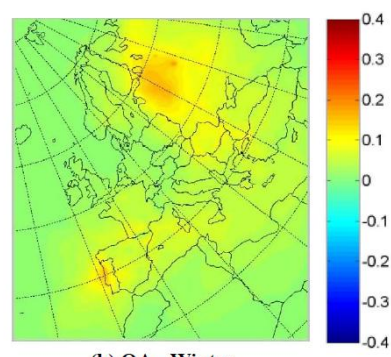

(b) OA - Winter

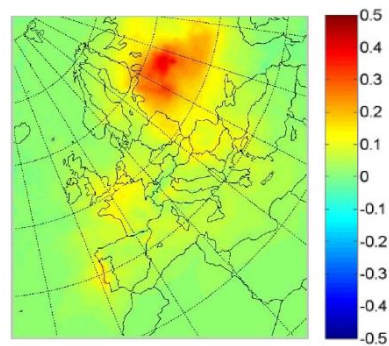

(d) $\mathrm{PM}_{2.5}-$ Winter
Fig. 7. Predicted reduction (base case - emissions reduction scenario) in ground-level concentrations $\left(\mu \mathrm{g} \mathrm{m}^{-3}\right)$ of (a-b) total OA and (c-d) total $\mathrm{PM}_{2.5}$ mass after a $50 \%$ reduction of anthropogenic VOCs emissions during the modeled summer and the modeled winter period. A positive value corresponds to a decrease.

$\mathrm{NO}_{\mathrm{x}}$-limited areas the increase of oxidant levels accelerates the VOC oxidation, offsetting some of this reduction. Additionally for sulfate, its gas-phase formation is affected by the competition between VOCs and $\mathrm{NO}_{\mathrm{x}}$ for the $\mathrm{OH}$ radical. In areas with high $\mathrm{NO}_{\mathrm{x}}$ concentration levels $\left(\mathrm{NO}_{\mathrm{x}}\right.$-saturated areas), the conversion of $\mathrm{NO}$ to $\mathrm{NO}_{2}$ is VOC-limited and by reducing VOCs, ozone is reduced. This leads to lower $\mathrm{OH}$ concentrations slowing down the gas phase formation of sulfate. On the contrary in $\mathrm{NO}_{\mathrm{x}}$-limited areas (high $\mathrm{VOC} / \mathrm{NO}_{\mathrm{x}}$ ratio) the decrease of anthropogenic VOC emissions leads to increased $\mathrm{OH}$ levels, which reacts with $\mathrm{SO}_{2}$ forming additional particulate sulfate.

During the modeled summer period, the VOC control reduces total OA levels in the whole domain (Fig. 7a). The predicted decrease is mainly attributed to the response $(50 \%$ on average) of anthropogenic SOA. Anthropogenic VOCs are precursors of SOA and therefore a $50 \%$ reduction of their emissions leads to decreased aSOA. In areas where aSOA levels are predicted to be high (Central and Western Europe) the VOC control is more effective for reducing total OA $\left(0.2 \mu \mathrm{g} \mathrm{m}^{-3}\right.$ or $9 \%$ reduction of total OA in these areas) (Table 2). On average, aSOA accounts for almost $90 \%$ of the $\mathrm{OA}$ reduction. However, most of the model domain during summer is $\mathrm{NO}_{\mathrm{x}}$-limited. Thus, the expected increase of oxidant levels will lead to increases of sulfate and ammonium nitrate concentration (Table 2). The predicted increases of inorganic $\mathrm{PM}_{2.5}$ components are less than the decreases of total OA, therefore the VOC reduction leads to a net reduction of total $\mathrm{PM}_{2.5}$ concentration. However, the predicted decrease of total $\mathrm{PM}_{2.5}$ is modest, up to $0.2 \mu \mathrm{g} \mathrm{m}^{-3}(1.1 \%)$ over Western Europe (Fig. 7c).

In the modeled winter period, the VOC reduction leads also to a decrease of total OA levels (Fig. 7b), due to the reduction of aSOA. However the response of OA is lower compared to summertime due to the lower aSOA levels during this period. The impact of the VOCs control is relatively uniform in space with the highest decreases of approximately $0.07 \mathrm{~g} \mathrm{~m}^{-3}(4 \%)$ predicted in North Europe. In this area aSOA levels were found to be high. In addition, decreases are also predicted, in most of the domain, for inorganic $\mathrm{PM}_{2.5}$ components (Table 2), due to the decrease of oxidant levels. The predicted reductions of inorganic $\mathrm{PM}_{2.5}$ are marginal and along with the total OA reduction lead to small decreases of $\mathrm{PM}_{2.5}$ levels (Fig. 7d, Table 2).

\subsection{Reduction of anthropogenic POA emissions}

The $50 \%$ reduction of primary OA emissions significantly reduces total OA levels, in both periods, especially in areas close to emissions sources (Fig. 8). During the modeled summer period, OA is reduced by $8 \%$ on average, with peak reductions in Western and Central Europe, where OA decreases by $0.26 \mu \mathrm{g} \mathrm{m}^{-3}(11 \%)$ and $0.24 \mu \mathrm{g} \mathrm{m}^{-3}(10 \%)$ respectively (Table 2). The impact on OA levels is also significant in other areas of the domain, while close to emissions sources the OA is reduced even more (e.g. in areas over North and Central Europe the predicted decrease reaches $3.6 \mu \mathrm{g} \mathrm{m}^{-3}(34 \%)$ and $2 \mu \mathrm{g} \mathrm{m}^{-3}(32 \%)$ respectively). The predicted response of total OA is mainly explained from the almost linear decrease of fresh anthropogenic POA concentration after the POA control strategy. Fresh POA is reduced by $50 \%$ in the whole domain and it accounts for approximately $55 \%$ of OA reduction. The additional decrease of oxidized POA $(6 \%$ on average) contributes $38 \%$ to the $\mathrm{OA}$ concentration decrease. The decrease of primary OA emissions affects also $\mathrm{OH}$ levels through the corresponding reaction of the evaporated organic vapors, and eventually increases the production of nitric and sulphuric acid from $\mathrm{NO}_{2}$ and $\mathrm{SO}_{2}$ oxidation respectively. This can result in higher nitrate and sulfate levels, changes that can be significant during specific periods in major urban areas. During the modeled summer period, increases of nitrate, on an hourly basis, reach as much as $1.5 \mu \mathrm{g} \mathrm{m}^{-3}(25 \%)$ while sulfate increases up to $0.6 \mu \mathrm{g} \mathrm{m}^{-3}(15 \%)$. However, the corresponding concentration changes are quite small when averaged over the whole simulation period, indicating that the average effect of primary OA emissions on inorganic $\mathrm{PM}_{2.5}$ components is on average quite small (Fig. 9a, Table 2).

In the modeled winter period the higher levels of fresh POA make the POA control strategy more effective in reducing total OA levels. Total OA is predicted to decrease in the entire domain (15\% on average) (Fig. 8b), while POA control has the highest impact on its concentrations over Central and North Europe, where total OA is reduced by $0.35 \mu \mathrm{g} \mathrm{m}^{-3}$ 


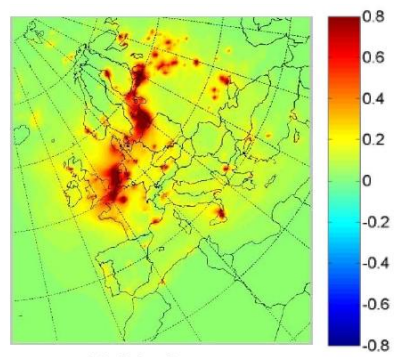

(a) $\mathrm{OA}$ - Summer

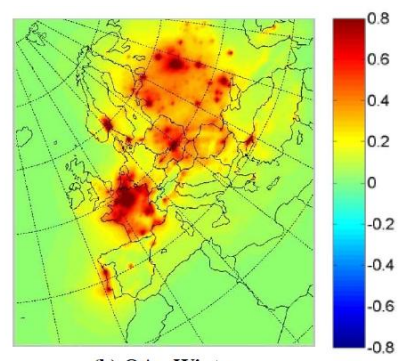

(b) $\mathrm{OA}$ - Winter

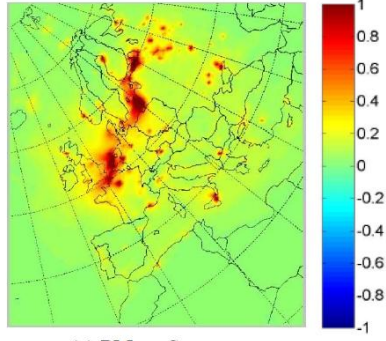

(a) $\mathrm{PM}_{2.5}$ - Summer

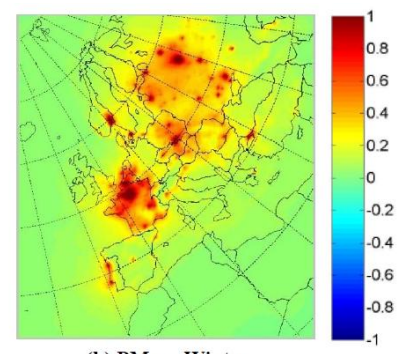

(b) $\mathbf{P M}_{2.5}-$ Winter

Fig. 8. Predicted reduction (base case - emissions reduction scenario) in ground-level concentrations $\left(\mu \mathrm{g} \mathrm{m}^{-3}\right)$ of total OA after a $50 \%$ reduction of anthropogenic POA emissions during (a) the modeled summer period and (b) the modeled winter period. A positive value corresponds to a decrease.

(25\%) and $0.3 \mu \mathrm{g} \mathrm{m}^{-3}(18 \%)$ respectively. This OA reduction is primarily due to fresh POA, which contributes $78 \%$ to the OA decrease and secondly to the decrease of oxidized POA (18\% contribution). Similarly to summertime, the decrease of primary OA does increase nitrate and sulfate levels for specific areas and periods by as much as $0.2 \mu \mathrm{g} \mathrm{m}^{-3}(5 \%)$ and $0.5 \mu \mathrm{g} \mathrm{m}^{-3}(25 \%)$ respectively. However, the monthly average effect of primary OA emissions on inorganic $\mathrm{PM}_{2.5}$ components is small and the respective reductions of total $\mathrm{PM}_{2.5}$ levels are due almost exclusively to the predicted $\mathrm{OA}$ decreases (Fig. 9b, Table 2).

\section{Effects of temperature increase}

In order to determine the sensitivity of fine PM to temperature we used two simplified scenarios: a uniform increase of 2.5 and of $5 \mathrm{~K}$ over the entire domain. This sensitivity test, quantifies the effect of a temperature increase on $\mathrm{PM}_{2.5} \mathrm{lev}$ els keeping the rest of the meteorological parameters constant. We assumed temperature sensitive biogenic emissions using the MEGAN model. In addition, dry deposition was simulated assuming temperature dependence for stomatal resistance. The results of these higher temperature scenarios were compared with those of the baseline scenarios for each simulation period (summer and winter).

Figure 10 shows the predicted changes (base case - increased temperature scenario) in ground-level concentrations of total $\mathrm{PM}_{2.5}$ after a $2.5 \mathrm{~K}$ temperature increase. During the modeled summer period $\mathrm{PM}_{2.5}$ is reduced in Central Europe due to a significant decrease of ammonium nitrate in this area (18\% on average). A slight decrease of fresh anthropogenic POA due to evaporation decreases even more $\mathrm{PM}_{2.5}$. The highest reduction of approximately $1 \mu \mathrm{g} \mathrm{m}^{-3}(5 \%)$ is predicted in Germany (Fig. 10a) where the respective decrease of ammonium nitrate is $1.1 \mu \mathrm{g} \mathrm{m}^{-3}(22 \%)$. Significant decrease of $\mathrm{PM}_{2.5}$ is also predicted in areas where ammonium nitrate concentration is high such as the United Kingdom and

Fig. 9. Predicted reduction (base case - emissions reduction scenario) in ground-level concentrations $\left(\mu \mathrm{g} \mathrm{m}^{-3}\right.$ ) of total $\mathrm{PM}_{2.5}$ after a $50 \%$ reduction of anthropogenic POA emissions during (a) the modeled summer period and (b) the modeled winter period. A positive value corresponds to a decrease.

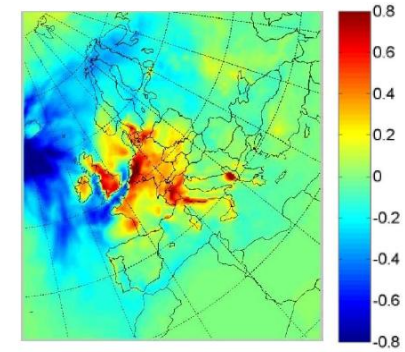

(a) $\mathbf{P M}_{2.5}$ - Summer

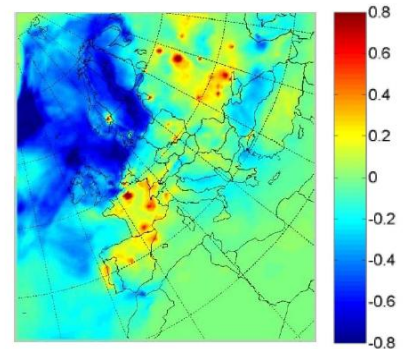

(b) $\mathrm{PM}_{2.5}$ - Winter
Fig. 10. Predicted reduction (base case - increased temperature scenario) in ground-level concentrations $\left(\mu \mathrm{g} \mathrm{m}^{-3}\right)$ of total $\mathrm{PM}_{2.5}$ after a $2.5 \mathrm{~K}$ increase of temperature during (a) the modeled summer period and (b) the modeled winter period. A positive value corresponds to a decrease.

Italy. However in North Europe and also in areas in Southwest Europe and in the Balkans, the response of $\mathrm{PM}_{2.5}$ to temperature increase differs. In these areas $\mathrm{PM}_{2.5}$ is predicted to increase mainly due to increase of sulfate and total OA. The increase of oxidant levels from the temperature rise which favours the oxidation of $\mathrm{SO}_{2}$, explain the sulfate response. The increase of total $\mathrm{OA}$ is mainly attributed to the increase in biogenic VOC emissions and the corresponding increase of biogenic SOA in association with a slight increase of anthropogenic SOA due to acceleration of its chemical production and aging (Day and Pandis, 2011). The increase of oxidant levels and the corresponding increase of sulfate lead also to an increase of total $\mathrm{PM}_{2.5}$ over the Atlantic. In North Europe $\mathrm{PM}_{2.5}$ is increased up to $0.5 \mu \mathrm{g} \mathrm{m}^{-3}$ (12\%) (Fig. 10a), while sulfate, biogenic and anthropogenic SOA are predicted to increase up to $14 \%$ and $20 \%$ and $7 \%$ respectively.

In the modeled winter period, the reduction of fresh anthropogenic POA due to evaporation dominates (35\% on average) and along with a reduction of ammonium nitrate (5\% on average) result in a decrease of total $\mathrm{PM}_{2.5}$ mostly in areas over Central and North Europe. The highest decrease 


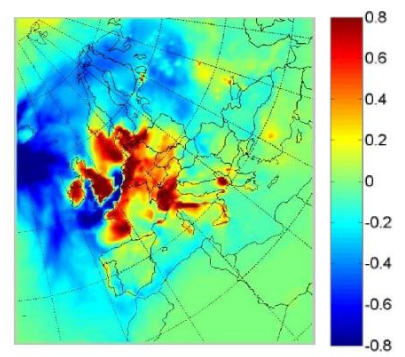

(a) $\mathbf{P M}_{2.5}$ - Summer

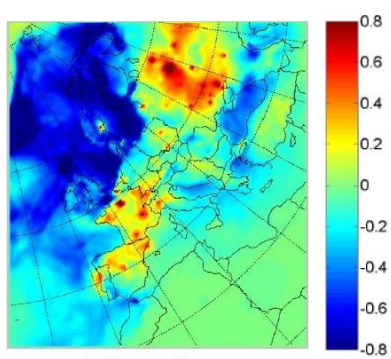

(b) $\mathrm{PM}_{2.5}$ - Winter

Fig. 11. Predicted reduction (base case - increased temperature scenario) in ground-level $\left(\mu \mathrm{g} \mathrm{m}^{-3}\right)$ concentrations of total $\mathrm{PM}_{2.5}$ after a $5 \mathrm{~K}$ increase of temperature during (a) the modeled summer period and (b) the modeled winter period. A positive value corresponds to a decrease.

for $\mathrm{PM}_{2.5}$ is predicted in Paris (approximately $4.5 \mu \mathrm{g} \mathrm{m}^{-3}$ or $12 \%$ ) (Fig. 10b) where anthropogenic POA is decreased by $4.9 \mu \mathrm{g} \mathrm{m}^{-3}$ or $37 \%$. The high OA levels in Paris (consistent with the conclusions of the MEGAPOLI campaigns) (Crippa et al., 2013) as well as in a lot of European major urban centers in the winter, were mainly due to a combination of weak vertical mixing and higher emissions from home heating and residential wood burning. Thus, the significant reduction of fresh POA as temperature increases during winter, in association with the small biogenic SOA contribution to total OA due to lower biogenic emissions lead to a different response of total OA to temperature increase. The wintertime total OA levels are predicted to decrease for warmer conditions with a predicted maximum decrease in Paris $\left(4.7 \mu \mathrm{g} \mathrm{m}^{-3}\right.$ or $35 \%$ ). On the contrary the increase of the oxidant levels affects sulfate levels and lead to an increase of $\mathrm{PM}_{2.5}$ in many areas of Europe. The predicted increase of $\mathrm{PM}_{2.5}$ is highest over North Europe reaching a maximum of $1.3 \mu \mathrm{g} \mathrm{m}^{-3}$ $(15 \%)$ (Fig. 10b). In this area sulfate is increased by $24 \%$ on average.

The doubling of temperature increase (from 2.5 to $5 \mathrm{~K}$ ) during the modeled summer period almost doubles the corresponding concentration change of all OA components. This OA response followed by higher concentration changes of inorganic $\mathrm{PM}_{2.5}$ result in even larger changes for total $\mathrm{PM}_{2.5}$ concentration. $\mathrm{PM}_{2.5}$ is predicted to decrease even more in Central Europe (up to $1.5 \mu \mathrm{g} \mathrm{m}^{-3}$ or $8 \%$ ) (Fig. 11a), mainly due to the larger decrease of ammonium nitrate ( $27 \%$ on average) and the doubling of anthropogenic POA decrease. On the contrary the higher increase of sulfate along with the linear response of biogenic and anthropogenic SOA to the temperature change account for the higher $\mathrm{PM}_{2.5}$ increase (up to $1.2 \mu \mathrm{g} \mathrm{m}^{-3}$ or $4.5 \%$ ) (Fig. 11a).

Similarly to the modeled summer period, the increase in temperature by $5 \mathrm{~K}$, during wintertime, leads to a higher corresponding concentration change of total $\mathrm{PM}_{2.5}$. The larger decrease of anthropogenic POA ( $40 \%$ on average), due to evaporation, associated with a decrease on ammonium ni-

trate ( $8 \%$ on average) lead to a decrease of $\mathrm{PM}_{2.5}$ in Central and North Europe with a predicted maximum decrease of $4.9 \mathrm{~g} \mathrm{~m}^{-3}(14 \%)$ in Paris (Fig. 11b). On the other hand the larger increase in sulfate concentration dominates in many areas over Europe, increasing total $\mathrm{PM}_{2.5}$ (up to $1.6 \mu \mathrm{g} \mathrm{m}^{-3}$ or $18 \%$ in North Europe) (Fig. 11b).

Table 3 summarizes the temperature increase scenarios and the corresponding response of the major $\mathrm{PM}_{2.5}$ components during the modeled summer and winter periods.

\section{Discussion}

A recent modelling study from Aksoyoglu et al. (2011) who used a three dimensional CTM over Europe with a focus on Switzerland, showed that in most of European areas the reduction of $\mathrm{NH}_{3}$ emissions by $50 \%$ during winter, is more effective in reducing total $\mathrm{PM}_{2.5}$ than reductions of other gas precursors. During summer the effect of $\mathrm{NH}_{3}$ emissions on $\mathrm{PM}_{2.5}$ concentrations was predicted to be lower mostly due to lower ammonium nitrate concentrations. The wintertime effectiveness of $\mathrm{NH}_{3}$ emissions in reducing $\mathrm{PM}_{2.5}$ levels has been reported also in studies conducted in the US (Tsimpidi et al., 2007; Odman, 2009). Our results for winter are quite consistent with all these previous studies. However our findings suggest these reductions in $\mathrm{NH}_{3}$ could be also efficient during the summer for at least parts of Europe something that has not been reported in previous studies (Aksoyoglu et al., 2011).

Berglen et al. (2007) quantified the negative trend in sulfate concentrations over Europe during the last two decades as a result of reduced $\mathrm{SO}_{2}$ emissions. The significant expected impact of $\mathrm{SO}_{2}$ control on sulfate levels is also reproduced by our model, showing significant local non-linear effects on sulfate. This non-linear response of sulfate to $\mathrm{SO}_{2}$ reductions was also reported by Lövblad et al. (2004). In addition our model predicts increases of nitrate levels due to $\mathrm{SO}_{2}$ reduction. Similar findings have been reported by other studies (Fagerli et al., 2008; Tsimpidi et al., 2007). These results suggest that $\mathrm{SO}_{2}$ reduction could be effective for improving air quality, by reducing total $\mathrm{PM}_{2.5}$, especially in areas where sulfate concentration is high and mainly during summer.

Reduction of the $\mathrm{NO}_{\mathrm{x}}$ emissions by $50 \%$ during the modeled summer period is predicted to increase average ozone levels in major European cities by several ppb (up to $8 \mathrm{ppb}$ or $43 \%$ in London), as well as in Western Europe, while in rest of Europe $\mathrm{O}_{3}$ levels are reduced. The same increases of $\mathrm{O}_{3}$ concentration in urban centers have been reported by Thunis et al. (2007). This summertime response of ozone to $\mathrm{NO}_{\mathrm{x}}$ emissions is consistent with the results of Jonson et al. (2001). Thunis et al. (2007) predicted also decreases of total PM concentration after the $\mathrm{NO}_{\mathrm{x}}$ reduction, although, without investigating the corresponding impacts that $\mathrm{NO}_{\mathrm{x}}$ control has on individual PM components (e.g. our model 
Table 3. Response of the major $\mathrm{PM}_{2.5}$ components to a 2.5 and $5 \mathrm{~K}$ increase of temperature, and percent average predicted reduction of total $\mathrm{PM}_{2.5}$, during the modelled summer and the modelled winter period.

\begin{tabular}{|c|c|c|c|c|c|c|}
\hline \multirow[t]{2}{*}{ Increase Scenario } & \multirow[t]{2}{*}{ Season } & \multirow[t]{2}{*}{ Average $\mathrm{PM}_{2.5}$ Reduction } & \multicolumn{4}{|c|}{ Change of Component } \\
\hline & & & Ammonium & Sulfate & Nitrate & Total OA \\
\hline \multirow[t]{2}{*}{$+2.5 \mathrm{~K}$} & Summer & $-0.8 \% *$ & $\downarrow$ & $\uparrow$ & $\Downarrow$ & $\uparrow$ \\
\hline & Winter & $-1 \%$ & $\downarrow$ & $\Uparrow$ & $\downarrow$ & $\Downarrow$ \\
\hline \multirow[t]{2}{*}{$+5 \mathrm{~K}$} & Summer & $-1 \%$ & $\downarrow$ & $\uparrow$ & $\Downarrow$ & $\uparrow$ \\
\hline & Winter & $-5.7 \%$ & $\downarrow$ & $\Uparrow$ & $\downarrow$ & $\Downarrow$ \\
\hline
\end{tabular}

$\Downarrow>10 \%$ reduction $\quad \Uparrow>10 \%$ increase $\quad \downarrow<10 \%$ reduction $\quad \uparrow<10 \%$ increase

predicts increases of OA and sulfate over Western Europe, during the modeled summer period). In addition our results are consistent with the conclusions of de Meij et al. (2009a), who showed that the reduction of $\mathrm{NO}_{\mathrm{x}}$ emissions along with a reduction of $\mathrm{PM}_{2.5}$ emissions leads to significant decrease of total $\mathrm{PM}_{2.5}$ levels over PoValley and to increases of $\mathrm{O}_{3}$ in Milan. On the contrary, the predicted net increase of total $\mathrm{PM}_{2.5}$ over Europe, due to $\mathrm{NO}_{\mathrm{x}}$ reduction in the winter, is not consistent with the conclusions of Aksoyoglu et al. (2011) who reported that $\mathrm{NO}_{\mathrm{x}}$ control could reduce total $\mathrm{PM}_{2.5}$ levels during winter.

The reduction of primary OA emissions, results in a significant decrease of total OA concentrations and to a consequent reduction of total $\mathrm{PM}_{2.5}$ levels. The relative effects of primary OA emissions to $\mathrm{PM}_{2.5}$ levels were found to be quite local, having the highest impact in areas close to emissions sources. This local effectiveness of primary OA reduction has also been shown in other studies (Odman et al., 2009). The significant effect that primary OA emissions have on $\mathrm{OA}$ levels along with a respective reduction of $\mathrm{NH}_{3}$ emissions, which is effective in reducing inorganic $\mathrm{PM}_{2.5}$, could be a favourable control strategy. Generally, a coupled emissions reduction of the major precursors could have better results than individual control strategies. Investigation of these more complex multi-pollutant reductions is outside the scope of this study and will be the topic of future work.

Our results suggest that a temperature increase will lead to lower levels of particulate ammonium nitrate, while biogenic SOA, mainly during summer will increase due to high biogenic VOCs emissions. The decrease of nitrate levels over the continental Europe, as temperature rises, was also shown by Aksoyoglu et al. (2011), while the predicted increases of biogenic SOA are consistent with other studies (Heald et al., 2008).

There are several issues that need further investigation regarding the system response to emission and temperature changes. These knowledge gaps include uncertainties in emission inventories which could lead to significant discrepancies in air quality modeling simulations. Uncertainties associated with the modelling of emissions and removal of $\mathrm{NH}_{4} \mathrm{NO}_{3}$ precursors, its formation and partitioning to both the fine and coarse particles are still a significant modelling topic. The use of the bulk equilibrium approach in our simulations and the fact that in some areas (e.g. Mace Head) a significant amount of nitrate is associated with sea salt, which shifts nitrate and ammonium to the coarse mode, could lead to significant overpredictions of nitrate concentration in the fine mode. A more detailed but computationally demanding, method, such as the "hybrid" approach could give better estimates for nitrate levels in areas with levels of coarse particles and significant ammonia levels. In addition, the uncertainties inherent in OA modelling are still a challenge. In this work we showed that the reduction of anthropogenic VOCs and primary OA emissions lead to decreases of OA levels, although the predicted changes are quite uncertain. Further investigation based on improved descriptions of the volatility distribution of the primary organic aerosol emissions and better parameterization of the chemical aging of the OA are required to improve the accuracy of the predictions. These uncertainties have been discussed in previous studies (Lane et al., 2008a, b; Murphy et al., 2009, 2010; Tsimpidi et al., 2010, 2011).

\section{Conclusions}

A detailed three dimensional chemical transport model, PMCAMx-2008, was applied to the European domain to evaluate the response of fine aerosol $\left(\mathrm{PM}_{2.5}\right)$ mass concentration to changes in emissions of precursor gases $\left(\mathrm{SO}_{2}, \mathrm{NH}_{3}\right.$, $\mathrm{NO}_{\mathrm{x}}, \mathrm{VOCs}$ ) and anthropogenic primary OA (POA) as well as to changes in temperature.

The reduction of $\mathrm{NH}_{3}$ emissions by $50 \%$ seems to be the most effective control strategy in reducing $\mathrm{PM}_{2.5}$, in both periods mainly due to a significant decrease of ammonium nitrate. During the modeled summer period, $\mathrm{NH}_{3}$ emissions reduction resulted in a decrease of ammonium by $22 \%$ in the entire model domain. Nitrate is reduced by $39 \%$ in Western Europe and by $30 \%$ in Southwest Europe, while the corresponding decrease of total $\mathrm{PM}_{2.5}$ in these areas was $15 \%$ and $10 \%$ respectively. Similarly in the modeled winter period, the $\mathrm{NH}_{3}$ control produces a significant reduction of 
ammonium nitrate levels in most areas over Europe. Overall, ammonium nitrate reduction accounts for almost $80 \%$ of total $\mathrm{PM}_{2.5}$ reduction in both periods. The reduction of $\mathrm{NH}_{3}$ produces also a slight decrease of sulfate levels due to the effect of $\mathrm{NH}_{3}$ on cloud $\mathrm{pH}$ and on the rate of in-cloud sulfate production.

The $50 \%$ reduction of $\mathrm{SO}_{2}$ emissions, during the modeled summer period, leads to a significant and non-linear decrease of sulfate in the entire domain ( $23 \%$ on average). The $\mathrm{SO}_{2}$ control strategy is more effective over the Balkans where sulfate is reduced by $34 \%$, while the respective decrease of total $\mathrm{PM}_{2.5}$ was $10 \%$. Ammonium is also reduced by $8 \%$ on average mainly due to the decrease of ammonium sulfate. During the summer period the $\mathrm{SO}_{2}$ control strategy produces also a significant increase of nitrate in most of the model domain (16\% on average). Nevertheless, the predicted increases of nitrate are less than sulfate decreases; thus, the net impact on total $\mathrm{PM}_{2.5}$ levels is a reduction. In the modeled winter period sulfate is reduced by $15 \%$ on average after a $50 \%$ reduction of $\mathrm{SO}_{2}$ emissions. The lower decrease of sulfate, because its formation was limited by $\mathrm{H}_{2} \mathrm{O}_{2}$ availability, as well as the higher increase of nitrate make $\mathrm{SO}_{2}$ emissions reduction less effective in winter.

The $50 \%$ reduction of anthropogenic VOCs and POA produced a decrease of total OA concentration in both periods with the POA control strategy to be more effective in areas close to emissions sources. By reducing VOCs emissions total OA is predicted to decrease in the whole domain by $8 \%$ during summertime and $4 \%$ in the modeled winter period, mainly due to the almost linear response of anthropogenic SOA (50\% decrease on average). Anthropogenic POA responded linearly (an average reduction of $50 \%$ in the whole domain) to the $50 \%$ reduction of POA emissions, while the respective average decrease of total OA was $15 \%$ during the modeled winter period (25\% in Central Europe) and $8 \%$ in the summer period. Both control strategies produce small (VOC reduction) or negligible (POA reduction) changes on monthly average inorganic $\mathrm{PM}_{2.5}$ levels, in both periods.

On the contrary, the $\mathrm{NO}_{\mathrm{x}}$ emissions control strategy seems to be problematic in both periods. During the modeled summer period, the $50 \%$ reduction of $\mathrm{NO}_{\mathrm{x}}$ emissions produces a significant decrease of ammonium nitrate in the whole domain ( $25 \%$ on average), but it also leads to an increase of ozone levels (based to $\mathrm{VOC} / \mathrm{NO}_{\mathrm{x}}$ ratio), mainly in the major urban areas such as London, Paris and Madrid, and also in the Western Europe. The ozone increase exceeds $10 \%$ in these urban centers while in Western Europe ozone is predicted to increase by $4 \%$ on average. Because of this increment, sulfate and total OA are predicted to increase in these areas $(5 \%$ and $6 \%$ respectively). Additionally, in the winter period, ammonium nitrate is reduced by $17 \%$, however the reduction of $\mathrm{NO}_{\mathrm{x}}$ emissions results in an increase of sulfate and total OA and eventually to a net increase of total $\mathrm{PM}_{2.5}$.
The increase of temperature by $2.5 \mathrm{~K}$ results in a decrease of ammonium nitrate and fresh anthropogenic POA in both periods. During the modeled summer period, ammonium nitrate is reduced by $10 \%$ (18\% in Central Europe), while anthropogenic POA is decreased by $7 \%$ due to evaporation. However, the temperature rise during summertime resulted in an increase of sulfate due to an increase of oxidant levels which favor the oxidation of $\mathrm{SO}_{2}$. Biogenic SOA is also predicted to increase because of the higher biogenic VOC emissions from the temperature increase, leading to an increase of total OA in most of the model domain. During the modeled winter period, total $\mathrm{OA}$ is predicted to decrease for warmer conditions. This different response is due to the dominance of anthropogenic POA reduction (35\% decrease in the whole domain) along with the small biogenic SOA contribution to total OA due to lower biogenic emissions. The wintertime ammonium nitrate levels are also decreased, mainly in Central and North Europe (6\% in both areas) while sulfate is predicted to increase due to the increase of oxidant levels. The doubling of temperature increase (from $2.5 \mathrm{~K}$ to $5 \mathrm{~K}$ ) approximately doubles the corresponding concentration change of OA components during summer and leads to even larger concentration changes of inorganic $\mathrm{PM}_{2.5}$, in both periods.

The significant impact that the emissions reductions of the major gaseous and particulate precursors may have on $\mathrm{PM}_{2.5}$ levels, as well as the sensitivity of $\mathrm{PM}_{2.5}$ concentrations to temperature changes should be of significant concern for atmospheric PM composition and air quality. The above results indicate that the challenge of improving air quality needs understanding the relative effects that emissions and climate change could have on particulate matter.

\section{Supplementary material related to this article is available online at: http://www.atmos-chem-phys.net/13/ 3423/2013/acp-13-3423-2013-supplement.pdf.}

Acknowledgements. This work was funded by the European Commission 7th Framework Programme project PEGASOS (Grant Agreement 265148) and the European Research Council project ATMOPACS (Grant Agreement 267099).

Edited by: E. Nemitz 


\section{References}

Aksoyoglu, S., Keller, J., Barmpadimos, I., Oderbolz, D., Lanz, V. A., Prévôt, A. S. H., and Baltensperger, U.: Aerosol modelling in Europe with a focus on Switzerland during summer and winter episodes, Atmos. Chem. Phys., 11, 7355-7373, doi:10.5194/acp11-7355-2011, 2011.

Ansari, A. S. and Pandis, S. N.: Response of inorganic $\mathrm{PM}_{2.5}$ to precursor concentrations, Environ. Sci. Technol., 32, 2706-2714, 1998.

Argueso, D, Hidalgo-Munoz, J. M., Gamiz-Fortis, S. R., and Esteban-Parra, M. J.: Evaluation of WRF parameterizations for climate studies over Southern Spain using a multistep regionalization, J. Climate, 24, 5633-5651, 2011.

Berglen, T. F., Myhre, G., Isaksen, I. S. A., Vestreng, V., and Smith, S. J.: Sulphate trends in Europe: are we able to model the recently observed decrease?, Tellus, 59, 773-786, 2007.

Blanchard, C. L. and Stoeckenius, T.: Ozone response to precursor controls: Comparison of data analysis methods with the predictions of photochemical air quality simulation models, Atmos. Environ., 35, 1203-1215, 2001.

Blanchard, C. L., Tanenbaum, S., and Hidy, G. M.: Effects of sulfur dioxide and oxides of nitrogen emission reductions on fine particulate matter mass concentrations: Regional comparisons, J. Air Waste Manage., 57, 1337-1350, 2007.

Burtraw, D., Krupnick, A., Mansur, E., Austin, D., and Farell, D.: Costs and benefits of reducing air pollutants related to acid rain, Contemp. Econ. Policy, 16, 379-400, doi:10.1111/j.14657287.1998.tb00527.x, 2007.

Capaldo, K. P., Pilinis, C., and Pandis, S. N.: A computationally efficient hybrid approach for dynamic gas/aerosol transfer in air quality models, Atmos. Environ., 34, 3617-3627, 2000.

Carter, W. P. L.: Programs and Files Implementing the SAPRC-99 Mechanism and its Associates Emissions Processing Procedures for Models-3 and Other Regional Models: http://www.cert.ucr. edu/ carter/SAPRC99/, last access: March 2013.

Carvalho, A., Monteiro, A., Solman, S., Miranda, A. I., and Borrego, C.: Climate-driven changes in air quality over Europe by the end of the 21st century, with special reference to Portugal, Environ. Sci. Policy, 13, 445-458, 2010.

Chock, D. P., Chang, T. Y., Winkler, S. L., and Nance, B. I.: The impact of an $8 \mathrm{~h}$ ozone air quality standard on $\mathrm{ROG}$ and $\mathrm{NO}_{\mathrm{x}}$ controls in Southern California, Atmos. Environ., 33, 2471-2485, 1999.

Constable, J. V. H., Guenther, A. B., Schimel, D. S., and Monson, R. $\mathrm{K}$.: Modeling changes in VOC emissions in response to climate change in the continental United States, Global Change Biol., 5, 791-806, 1999.

Crippa, M., DeCarlo, P. F., Slowik, J. G., Mohr, C., Heringa, M. F., Chirico, R., Poulain, L., Freutel, F., Sciare, J., Cozic, J., Di Marco, C. F., Elsasser, M., Nicolas, J. B., Marchand, N., Abidi, E., Wiedensohler, A., Drewnick, F., Schneider, J., Borrmann, S., Nemitz, E., Zimmermann, R., Jaffrezo, J.-L., Prévôt, A. S. H., and Baltensperger, U.: Wintertime aerosol chemical composition and source apportionment of the organic fraction in the metropolitan area of Paris, Atmos. Chem. Phys., 13, 961-981, doi:10.5194/acp-13-961-2013, 2013.

Day, M. C. and Pandis, S. N.: Predicted changes in summertime organic aerosol concentrations due to increased temperature, Atmos. Environ., 45, 6546-6556, 2011.
Dall'Osto, M., Ceburnis, D., Martucci, G., Bialek, J., Dupuy, R., Jennings, S. G., Berresheim, H., Wenger, J., Healy, R., Facchini, M. C., Rinaldi, M., Giulianelli, L., Finessi, E., Worsnop, D., Ehn, M., Mikkilä, J., Kulmala, M., and O'Dowd, C. D.: Aerosol properties associated with air masses arriving into the North East Atlantic during the 2008 Mace Head EUCAARI intensive observing period: an overview, Atmos. Chem. Phys., 10, 8413-8435, doi:10.5194/acp-10-8413-2010, 2010.

de Meij, A., Thunis, P., Bessagnet, B., and Cuvelier, C.: The sensitivity of the CHIMERE model to emissions reduction scenarios on air quality in Northern Italy, Atmos. Environ., 43, 1897-1907, 2009a.

de Meij, A., Gzella, A., Cuvelier, C., Thunis, P., Bessagnet, B., Vinuesa, J. F., Menut, L., and Kelder, H. M.: The impact of MM5 and WRF meteorology over complex terrain on CHIMERE model calculations, Atmos. Chem. Phys., 9, 66116632, doi:10.5194/acp-9-6611-2009, 2009b.

Denier van der Gon, H. A. C, Visschedijk, A., van der Brugh, H., and Droge, R.: A high resolution European emission data base for the year 2005, TNO report TNO-034-UT-2010-01895 RPTML, Utrecht, the Netherlands, 2010.

Donahue, N. M., Robinson, A. L., Stanier, C. O., and Pandis, S. N.: Coupled partitioning, dilution, and chemical aging of semivolatile organics, Environ. Sci. Technol., 40, 2635-2643, 2006.

ENVIRON: User's Guide to the Comprehensive Air Quality Model with Extensions (CAMx), Version 4.02, Report, ENVIRON Int Corp., Novato, Calif. Available at: http://www.camx.com, 2003.

Erisman, J. W., Grennfelt, P., and Sutton, M.: The European perspective on nitrogen emission and deposition, Environ. Int., 29, 311-325, 2003.

EUCAARI deliverable D42: D42 Pan - European Carbonaceous aerosol inventory, EUCAARI deliverable report, Netherlands, TNO Built Environment and Geosciences, 2009.

Fagerli, H. and Wenche, A.: Trends of nitrogen in air and precipitation: Model results and observations at EMEP sites in Europe, 1980-2003, Environ. Pollut., 154, 448-461, 2008.

Fahey, K. and Pandis, S. N.: Optimizing model performance: variable size resolution in cloud chemistry modeling, Atmos. Environ., 35, 4471-4478, 2001.

Forkel, R. and Knoche, R.: Regional climate change and its impact on photooxidant concentrations in southern Germany: simulations with a coupled regional chemistry-climate model, J. Geophys. Res., 111, D12302, doi:10.1029/2005JD006748, 2006.

Forkel, R. and Knoche, R.: Nested regional climate-chemistry simulations for central Europe, C. R. Geosci., 339, 734-746, 2007.

Fountoukis, C., Racherla, P. N., Denier van der Gon, H. A. C., Polymeneas, P., Charalampidis, P. E., Pilinis, C., Wiedensohler, A., Dall'Osto, M., O'Dowd, C., and Pandis, S. N.: Evaluation of a three-dimensional chemical transport model (PMCAMx) in the European domain during the EUCAARI May 2008 campaign, Atmos. Chem. Phys., 11, 10331-10347, doi:10.5194/acp11-10331-2011, 2011.

Freney, E. J., Sellegri, K., Canonaco, F., Boulon, J., Hervo, M., Weigel, R., Pichon, J. M., Colomb, A., Prévôt, A. S. H., and Laj, P.: Seasonal variations in aerosol particle composition at the puy-de-Dôme research station in France, Atmos. Chem. Phys., 11, 13047-13059, doi:10.5194/acp-11-13047-2011, 2011. 
Ganor, E., Foner, H. A., Bingemer, H. G., Udisti, R., and Setter, I: Biogenic sulphate generation in the Mediterranean Sea and its contribution to the sulphate anomaly in the aerosol over Israel and the Eastern Mediterranean, Atmos. Environ., 36, 929-938, 2000.

Garcia-Diez, M., Fernandez, J., Fita, L., and Yague, C.: Seasonal dependence of WRF model biases and sensitivity to PBL schemes over Europe, Q. J. Roy. Meteor. Soc., 139, 501-514, doi:10.1002/qj.1976, 2012.

Gaydos, T., Koo, B., and Pandis, S. N.: Development and application of an efficient moving sectional approach for the solution of the atmospheric aerosol condensation/evaporation equations, Atmos. Environ., 37, 3303-3316, 2003.

Giorgi, F. and Meleux, F.: Modeling the regional effects of climate change on air quality, C. R. Geosci., 339, 721-733, 2007.

Guenther, A., Karl, T., Harley, P., Wiedinmyer, C., Palmer, P. I., and Geron, C.: Estimates of global terrestrial isoprene emissions using MEGAN (Model of Emissions of Gases and Aerosols from Nature), Atmos. Chem. Phys., 6, 3181-3210, doi:10.5194/acp-63181-2006, 2006.

Hamburger, T., McMeeking, G., Minikin, A., Birmili, W., Dall'Osto, M., O’Dowd, C., Flentje, H., Henzing, B., Junninen, H., Kristensson, A., de Leeuw, G., Stohl, A., Burkhart, J. F., Coe, H., Krejci, R., and Petzold, A.: Overview of the synoptic and pollution situation over Europe during the EUCAARILONGREX field campaign, Atmos. Chem. Phys., 11, 10651082, doi:10.5194/acp-11-1065-2011, 2011.

Heald, C. L., Henze, D. K., Horowitz, L. W., Feddema, J., Lamarque, J.-F., Guenther, A., Hess, P. G., Vitt, F., Seinfeld, J. H., Goldstein, A. H., and Fung, I.: Predicted change in global secondary aerosol concentrations in response to future climate, emissions and land use change, J. Geophys. Res., 113, D05211, doi:10.1029/2007JD009092, 2008.

Helmig, D., Ortega, J., Guenther, A., Herrick, J. D., and Geron, C.: Sesquiterpene emissions from loblolly pine and their potential contribution to biogenic aerosol formation in the Southeastern US, Atmos. Environ., 40, 4150-4157, 2006.

Hildebrandt, L., Engelhart, G. J., Mohr, C., Kostenidou, E., Lanz, V. A., Bougiatioti, A., DeCarlo, P. F., Prevot, A. S. H., Baltensperger, U., Mihalopoulos, N., Donahue, N. M., and Pandis, S. N.: Aged organic aerosol in the Eastern Mediterranean: the Finokalia Aerosol Measurement Experiment - 2008, Atmos. Chem. Phys., 10, 4167-4186, doi:10.5194/acp-10-4167-2010, 2010a.

Hildebrandt, L., Kostenidou, E., Mihalopoulos, N., Worsnop, D. R., Donahue, N. M., and Pandis, S. N.: Formation of highly oxygenated organic aerosol in the atmosphere: Insights from the Finokalia Aerosol Measurement Experiments, Geophys. Res. Lett., 37, L23801, doi:10.1029/2010GL045193, 2010 b.

Hodzic, A., Jimenez, J. L., Madronich, S., Canagaratna, M. R., DeCarlo, P. F., Kleinman, L., and Fast, J.: Modeling organic aerosols in a megacity: potential contribution of semi-volatile and intermediate volatility primary organic compounds to secondary organic aerosol formation, Atmos. Chem. Phys., 10, 5491-5514, doi:10.5194/acp-10-5491-2010, 2010.

Im, U., Markakis, K., Unal, A., Kindap, T., Poupkou, A., Incecik, S., Yenigun, O., Melas, D., Theodosi, C., and Mihalopoulos, N.: Study of a winter PM episode in Istanbul using the high resolution WRF/CMAQ modeling system, Atmos. Environ., 44, 3085-
3094, 2010.

Intergovernmental Panel on Climate Change (IPCC), Fourth Assessment Report: Summary for Policymakers, 2007.

Jacob, D. J. and Winner, D. A.: Effect of climate change on air quality, Atmos. Environ., 43, 51-63, 2009.

Jiang, W., Singleton, D. L., Hedley, M., and McLaren, R: Sensitivity of Ozone concentrations to VOC and $\mathrm{NO}_{\mathrm{x}}$ emissions in the Canadian lower Fraser Valley, Atmos. Environ., 31, 627-638, 1996.

Jimenez-Guerrero, P., Jorba, O., Baldasano, J. M., and Gasso, S.: The use of a modelling system as a tool for air quality management: Annual high-resolution simulations and evaluation, Sci. Total Environ., 390, 323-340, 2008.

Jonson, J. E., Sundet, J. K., and Tarrasón, L.: Model calculations of present and future levels of ozone and ozone precursors with a global and a regional model, Atmos. Environ., 35, 525-537, 2001.

Jonson, J. E., Simpson, D., Fagerli, H., and Solberg, S.: Can we explain the trends in European ozone levels?, Atmos. Chem. Phys., 6, 51-66, doi:10.5194/acp-6-51-2006, 2006.

Karydis, V. A., Tsimpidi, A. P., Fountoukis, C., Nenes, A., Zavala, M., Lei, W., Molina, L. T., and Pandis, S. N.: Simulating the fine and coarse inorganic particulate matter concentrations in a polluted megacity, Atmos. Environ., 44, 608-620, 2010.

Kleeman, M. J., Ying, Q., and Kaduwela, A.: Control strategies for the reduction of air borne particulate nitrate in California's San Joaquin Valley, Atmos. Environ., 39, 5325-5341, 2005.

Konovalov, I. B., Beekmann, M., Burrows, J. P., and Richter, A.: Satellite measurement based estimates of decadal changes in European nitrogen oxides emissions, Atmos. Chem. Phys., 8, 26232641, doi:10.5194/acp-8-2623-2008, 2008.

Koo, B., Pandis, S. N., and Ansari, A.: Integrated approaches to modeling the organic and inorganic atmospheric aerosol components, Atmos. Environ., 37, 4757-4768, 2003.

Kulmala, M., Asmi, A., Lappalainen, H. K., Baltensperger, U., Brenguier, J.-L., Facchini, M. C., Hansson, H.-C., Hov, Ø., O’Dowd, C. D., Pöschl, U., Wiedensohler, A., Boers, R., Boucher, O., de Leeuw, G., Denier van der Gon, H. A. C., Feichter, J., Krejci, R., Laj, P., Lihavainen, H., Lohmann, U., McFiggans, G., Mentel, T., Pilinis, C., Riipinen, I., Schulz, M., Stohl, A., Swietlicki, E., Vignati, E., Alves, C., Amann, M., Ammann, M., Arabas, S., Artaxo, P., Baars, H., Beddows, D. C. S., Bergström, R., Beukes, J. P., Bilde, M., Burkhart, J. F., Canonaco, F., Clegg, S. L., Coe, H., Crumeyrolle, S., D’Anna, B., Decesari, S., Gilardoni, S., Fischer, M., Fjaeraa, A. M., Fountoukis, C., George, C., Gomes, L., Halloran, P., Hamburger, T., Harrison, R. M., Herrmann, H., Hoffmann, T., Hoose, C., Hu, M., Hyvärinen, A., Hõrrak, U., Iinuma, Y., Iversen, T., Josipovic, M., Kanakidou, M., Kiendler-Scharr, A., Kirkevåg, A., Kiss, G., Klimont, Z., Kolmonen, P., Komppula, M., Kristjánsson, J.-E., Laakso, L., Laaksonen, A., Labonnote, L., Lanz, V. A., Lehtinen, K. E. J., Rizzo, L. V., Makkonen, R., Manninen, H. E., McMeeking, G., Merikanto, J., Minikin, A., Mirme, S., Morgan, W. T., Nemitz, E., O’Donnell, D., Panwar, T. S., Pawlowska, H., Petzold, A., Pienaar, J. J., Pio, C., Plass-Duelmer, C., Prévôt, A. S. H., Pryor, S., Reddington, C. L., Roberts, G., Rosenfeld, D., Schwarz, J., Seland, Ø., Sellegri, K., Shen, X. J., Shiraiwa, M., Siebert, H., Sierau, B., Simpson, D., Sun, J. Y., Topping, D., Tunved, P., Vaattovaara, P., Vakkari, V., Veefkind, J. P., Visschedijk, A., Vuollekoski, H., Vuolo, R., Wehner, B., Wildt, J., 
Woodward, S., Worsnop, D. R., van Zadelhoff, G.-J., Zardini, A. A., Zhang, K., van Zyl, P. G., Kerminen, V.-M., S Carslaw, K., and Pandis, S. N.: General overview: European Integrated project on Aerosol Cloud Climate and Air Quality interactions (EUCAARI) - integrating aerosol research from nano to global scales, Atmos. Chem. Phys., 11, 13061-13143, doi:10.5194/acp11-13061-2011, 2011.

Kumar, N., Lurmann, F. W., Wexler, A. S., Pandis, S., and Seinfeld, J. H.: Development and application of a three dimensional aerosol model. Presented at the AWMA Specialty Conference on Computing in Environmental Resource Management, Research Triangle Park, NC, 2-4 December, 1996.

Lane, T. E., Donahue, N. M., and Pandis, S. N.: Simulating secondary organic aerosol formation using the volatility basis-set approach in a chemical transport model, Atmos. Environ., 42, 7439-7451, 2008a.

Lane, T. E., Donahue, N. M., and Pandis, S. N.: Effect of $\mathrm{NO}_{\mathrm{x}}$ on secondary organic aerosol concentrations, Environ. Sci. Technol., 42, 6022-6027, 2008b.

Langner, J., Bergström, R., and Foltescu, V.: Impact of climate change on surface ozone and deposition of sulphur and nitrogen in Europe, Atmos. Environ., 39, 1129-1141, 2005.

Lelieveld, J., Berresheim, H., Borrmann, S., Crutzen, P. J., Dentener, F. J., Fischer, H., Feichter, J., Flatau, P. J., Holzinger, R., Korrmann, R., Lawrence, M. G., Levin, Z., Markowicz, K. M., Mihalopoulos, N., Minikin, A., Ramanathan, V., de Reus, M., Roelofs, G. J., Scheeren, H. A., Sciare, J., Schlager, H., Schultz, M., Siegmund, P., Steil, B., Stephanou, E. G., Stier, P., Traub, M., Warneke, C., Williams, J., and Ziereis, H.: Global air pollution crossroads over the Mediterranean, Science, 298, 794-799, 2002.

Lövblad, G., Tarrasón, L., Tørseth, K., and Dutchak, S.: EMEP Assessment Part I: European Perspective. Norwegian Meteorological Institute, P.O. Box 43, N-313 Oslo, Norway, 2004.

Makar, P. A., Moran, M. D., Zheng, Q., Cousineau, S., Sassi, M., Duhamel, A., Besner, M., Davignon, D., Crevier, L.-P., and Bouchet, V. S.: Modelling the impacts of ammonia emissions reductions on North American air quality, Atmos. Chem. Phys., 9, 7183-7212, doi:10.5194/acp-9-7183-2009, 2009.

Meleux, F., Solmon, F., and Giorgi, F.: Increase in summer European ozone amounts due to climate change, Atmos. Environ., 41, 7577-7587, 2007.

Meng, Z., Dadub, D., and Seinfeld, J. H.: Chemical coupling between atmospheric ozone and particulate matter, Science, 277, 116-119, 1997.

Mensah, A. A., Holzinger, R., Otjes, R., Trimborn, A., Mentel, Th. F., ten Brink, H., Henzing, B., and Kiendler-Scharr, A.: Aerosol chemical composition at Cabauw, The Netherlands as observed in two intensive periods in May 2008 and March 2009, Atmos. Chem. Phys., 12, 4723-4742, doi:10.5194/acp-12-4723-2012, 2012

Mihalopoulos, N., Stephanou, E., Kanakidou, M., Pilitsidis, S., and Bousquet, P.: Tropospheric aerosol ionic composition in the Eastern Mediterranean region, Tellus B, 49, 314-326, 1997.

Morgan, W. T., Allan, J. D., Bower, K. N., Highwood, E. J., Liu, D., McMeeking, G. R., Northway, M. J., Williams, P. I., Krejci, R., and Coe, H.: Airborne measurements of the spatial distribution of aerosol chemical composition across Europe and evolution of the organic fraction, Atmos. Chem. Phys., 10, 4065-4083, doi:10.5194/acp-10-4065-2010, 2010.

Mueller, S. F., Bailey, E. M., and Kelsoe, J. J: Geographic sensitivity of fine particle mass to emissions of $\mathrm{SO}_{2}$ and $\mathrm{NO}_{\mathrm{x}}$, Environ. Sci. Technol., 38, 570-580, 2004.

Murphy, B. N. and Pandis, S. N.: Simulating the formation of semivolatile primary and secondary organic aerosol in a regional chemical transport model, Environ. Sci. Technol., 43, 47224728, 2009.

Murphy, B. N. and Pandis, S. N.: Exploring summertime organic aerosol formation in the eastern United States using a regionascale budget approach and ambient measurements, J. Geophys. Res., 115, D24216, doi:10.1029/2010JD014418, 2010.

Nenes, A., Pandis, S. N., and Pilinis, C.: ISORROPIA: a new thermodynamic equilibrium model for multiphase multicomponent inorganic aerosols, Aquat. Geochem., 4, 123-152, 1998.

Nguyen, K. and Dabdub, D.: $\mathrm{NO}_{\mathrm{x}}$ and VOC control and its effects on the formation of aerosols, Aerosol Sci. Tech., 36, 560-572, 2002.

Odman, M. T., Hu, Y., Russell, A. G., Hanedar, A., Boylan, J. W., and Brewer, P. F.: Quantifying the sources of ozone, fine particulate matter, and regional haze in the Southeastern United States, J. Environ. Manage., 90, 3155-3168, 2009.

O’Dowd, C. D., Langmann, B., Varghese, S., Scannell, C., Ceburnis, D., and Facchini, M. C.: A Combined Organic-Inorganic Sea-Spray Source Function, Geophys. Res. Lett., 35, L01801, doi:10.1029/2007GL030331, 2008.

Ordóñez, C., Mathis, H., Furger, M., Henne, S., Hüglin, C., Staehelin, J., and Prévôt, A. S. H.: Changes of daily surface ozone maxima in Switzerland in all seasons from 1992 to 2002 and discussion of summer 2003, Atmos. Chem. Phys., 5, 1187-1203, doi:10.5194/acp-5-1187-2005, 2005.

Pandis, S. N. and Seinfeld, J. H.: Sensitivity analysis of a chemical mechanism for aqueous-phase atmospheric chemistry, J. Geophys. Res., 94, 1105-1126, 1989.

Pandis, S. N., Wexler, A. S., and Seinfeld, J. H.: Secondary organic aerosol formation and transport. 2. Predicting the ambient secondary organic aerosol size distribution, Atmos. Environ., 27A 2403-2416, 1993.

Pikridas, M., Bougiatioti, A., Hildebrandt, L., Engelhart, G. J., Kostenidou, E., Mohr, C., Prévôt, A. S. H., Kouvarakis, G., Zarmpas, P., Burkhart, J. F., Lee, B.-H., Psichoudaki, M., Mihalopoulos, N., Pilinis, C., Stohl, A., Baltensperger, U., Kulmala, M., and Pandis, S. N.: The Finokalia Aerosol Measurement Experiment - 2008 (FAME-08): an overview, Atmos. Chem. Phys., 10, 6793-6806, doi:10.5194/acp-10-6793-2010, 2010.

Pilinis, C., Capaldo, K. P., Nenes, A., and Pandis, S. N.: MADM - a new multicomponent aerosol dynamics model, Aerosol Sci. Tech., 32, 482-502, 2000.

Pinder, R. W., Adams, P. J., and Pandis, S. N.: Ammonia emission controls as a costeffective strategy for reducing atmospheric particulate matter in the eastern United States, Environ. Sci. Technol., 41, 380-386, 2007.

Poulain, L., Spindler, G., Birmili, W., Plass-Dülmer, C., Wiedensohler, A., and Herrmann, H.: Seasonal and diurnal variations of particulate nitrate and organic matter at the IfT research station Melpitz, Atmos. Chem. Phys., 11, 12579-12599, doi:10.5194/acp-11-12579-2011, 2011.

Pun, B. K. and Seigneur, C.: Sensitivity of particulate matter nitrate formation to precursor emissions in the California San Joaquin 
Valley, Environ. Sci. Technol., 35, 2979-2987, 2001.

Pun, B. K., Seigneur, C., Bailey, E. M., Gautney, L. L., Douglas, S. G., Haney, J. L., and Kumar, N.: Response of atmospheric particulate matter to changes in precursor emissions: a comparison of three air quality models, Environ. Sci. Technol., 42, 831-837, 2008.

Robinson, A. L., Donahue, N. M., Shrivastava, M. K., Weitkamp, E. A., Sage, A. M., Grieshop, A. P., Lane, T. E., Pierce, J. R., and Pandis, S. N.: Rethinking organic aerosol: semivolatile emissions and photochemical aging, Science, 315, 1259-1262, 2007.

Russell, A. G., McRae, G. J., and Cass, G.: Verification of a mathematical model for aerosol nitrate and nitric acid formation and its use for control measure, Atmos. Environ., 20, 2001-2026, 1986.

Schaap, M., Roemer, M., Sauter, F., Boersen, G., Timmermans, R., and Builtjes, P. J. H.: LOTOS-EUROS Documentation, TNO report B\&O 2005/297, TNO, Apeldoorn, the Netherlands, 2005.

Sciare, J., Bardouki, H., Moulin, C., and Mihalopoulos, N.: Aerosol sources and their contribution to the chemical composition of aerosols in the Eastern Mediterranean Sea during summertime, Atmos. Chem. Phys., 3, 291-302, doi:10.5194/acp-3-291-2003, 2003.

Sehmel, G. A.: Particle and gas deposition: A review, Atmos. Environ., 14, 983-1011, 1967.

Seinfeld, J. H. and Pandis, S. N.: Atmospheric chemistry and physics: From air pollution to climate change. 2nd ed.; John Wiley and Sons, Hoboken, NJ, 2006.

Shrivastava, M. K., Lane, T. E., Donahue, N. M., Pandis, S. N., and Robinson, A. L.: Effects of gas-particle partitioning and aging of primary emissions on urban and regional organic aerosol concentrations, J. Geophys. Res., 113, D18301, doi:10.1029/2007JD009735, 2008.

Sillman, S., Vautard, R., Menut, L., and Kley, D.: $\mathrm{O}_{3}-\mathrm{NO}_{\mathrm{x}}-$ VOC sensitivity and $\mathrm{NO}_{\mathrm{x}}-\mathrm{VOC}$ indicators in Paris: Results from models and Atmospheric Pollution Over the Paris Area (ESQUIF) measurements, J. Geophys. Res., 108, 8563, doi:10.1029/2002JD001561, 2003.

Simpson, D.: Biogenic emissions in Europe 2. Implications for ozone control strategies, J. Geophys. Res., 100, 22891-22906, 1995.

Skamarock, W. C., Klemp, J. B., Dudhia, J., Gill, D. O., Barker, D. M., Wang, W., and Powers, J. G.: A Description of the Advanced Research WRF Version 2. NCAR Technical Note (http://www. mmm.ucar.edu/wrf/users/docs/arw_v2.pdf), 2005.

Slinn, S. A. and Slinn, W. G. N.: Predictions for particle deposition on natural waters, Atmos. Environ., 24, 1013-1016, 1980.

Sofiev, M., Vankevich, R., Lanne, M., Koskinen, J., and Kukkonen, J.: On integration of a Fire Assimilation System and a chemical transport model for near-real-time monitoring of the impact of wild-land fires on atmospheric composition and air quality, Modelling, Monitoring and Management of Forest Fires, WIT Trans. Ecol. Envir., 119, 343-351, 2008a.

Sofiev, M., Lanne, M., Vankevich, R., Prank, M., Karppinen, A., and Kukkonen, J.: Impact of wild-land fires on European air quality in 2006-2008, Modelling, Monitoring and Management of Forest Fires, WIT Trans. Ecol. Envir., 119, 353-361, 2008b.

Stanier, C. O., Donahue, N. M., and Pandis, S. N.: Parameterization of secondary organic aerosol mass fraction from smog chamber data, Atmos. Environ., 42, 2276-2299, 2008.
Stein, A. F. and Lamb, D.: The sensitivity of sulfur wet deposition to atmospheric oxidants, Atmos. Environ., 34, 1681-1690, 2000.

Stein, A. F. and Lamb, D.: Chemical indicators of sulfate sensitivity to nitrogen oxides and volatile organic compounds; J. Geophys. Res., 107, 4449, doi:10.1029/2001JD001088, 2002.

Stelson, A. W. and Seinfeld, J. H.: Thermodynamic prediction of the water activity, $\mathrm{NH}_{4} \mathrm{NO}_{3}$ dissociation constant, density and refractive index for the $\mathrm{NH}_{4} \mathrm{NO}_{3}-\left(\mathrm{NH}_{4}\right)_{2} \mathrm{SO}_{4}-\mathrm{H}_{2} \mathrm{O}$ System at $25^{\circ} \mathrm{C}$, Atmos. Environ., 16, 2507-2514, 1986.

Stockwell, W. R. and Calvert, J. G.: The mechanism of the HO-SO reaction, Atmos. Environ., 17, 2231-2235, 1983.

Sutton, M. A., Asman, W. A. H., Ellermann, T., Van Jaarsveld, J. A., Acker, K., Aneja, V., Duyzer, J., Horvath, L., Paramonov, S., Mitosinkova, M., Tang, Y. S., Achermann, B., Gauger, T., Bartniki, J., Neftel, A., and Erisman, J. W.: Establishing the link between ammonia emission control and measurements of reduced nitrogen concentrations and deposition, Environ. Monit. Assess., 82, 149-185, 2003.

Szopa, S., Hauglustaine, D., Vautard, R., and Menut, L.: Evolution of the tropospheric composition in 2030: impact on European air quality, Geophys. Res. Lett. 33, L14805, doi:10.1029/2006GL025860, 2006.

Thunis, P., Rouil, L., Cuvelier, C., Stern, R., Kerschbaumer, A., Bessagnet, B., Schaap, M., Builtjes, P., Tarrasón, L., Douros, J., Moussiopoulos, N., Pirovano, G., and Bedogni, M.: Analysis of model responses to emission-reduction scenarios within the CityDelta project, Atmos. Environ., 41, 208-220, 2007.

Tonnesen, G. S.: Effects of uncertainty in the reaction of the hydroxyl radical with nitrogen dioxide on model-simulated ozone control strategies, Atmos. Environ., 33, 1587-1598, 1998.

Tsimpidi, A. P., Karydis, V. A., and Pandis, S. N.: Response of inorganic fine particulate matters to emission changes of $\mathrm{SO}_{2}$ and $\mathrm{NH}_{3}$ : the Eastern United States as a case study, J. Air Waste Manage., 57, 1489-1498, 2007.

Tsimpidi, A. P., Karydis, V. A., and Pandis, S. N.: Response of fine particulate matter to emission changes of oxides of nitrogen and anthropogenic volatile organic compounds in the Eastern United States, J. Air Waste Manage., 58, 1463-1473, 2008.

Tsimpidi, A. P., Karydis, V. A., Zavala, M., Lei, W., Molina, L., Ulbrich, I. M., Jimenez, J. L., and Pandis, S. N.: Evaluation of the volatility basis-set approach for the simulation of organic aerosol formation in the Mexico City metropolitan area, Atmos. Chem. Phys., 10, 525-546, doi:10.5194/acp-10-525-2010, 2010.

Tsimpidi, A. P., Karydis, V. A., Zavala, M., Lei, W., Bei, N., Molina, L., and Pandis, S. N.: Sources and production of organic aerosol in Mexico City: insights from the combination of a chemical transport model (PMCAMx-2008) and measurements during MILAGRO, Atmos. Chem. Phys., 11, 5153-5168, doi:10.5194/acp11-5153-2011, 2011.

Tuovinen, J.-P., Simpson, D., Mayerhofer, P., Lindfors, V., and Laurila, T.: Surface ozone exposures in Northern Europe in changing environmental conditions, in: A Changing Atmosphere: Proceedings of the Eighth European Symposium on the Physico-Chemical Behaviour of Atmospheric Pollutants, edited by: Hjorth, J., Raes, F., and Angeletti, G., European Commission, DG Research, Joint Research Centre, CD-ROM, Paper AP61, 6 pp., 2002.

Van Loon, M., Vautard, R., Schaap, M., Bergström, R., Bessagnet, B., Brandt, J., Builtjes, P. J. H., Christensen, J. H., Cuvelier, K., 
Graf, A., Jonson, J. E., Krol, M., Langner, J., Roberts, P., Rouil, L., Stern, R., Tarrasón, L., Thunis, P., Vignati, E., White, L., and Wind, P.: Evaluation of long-term ozone simulations from seven regional air quality models and their ensemble average. Atmos. Environ., 41, 2083-2097, 2007.

Vautard, R., Szopa, S., Beekmann, M., Menut, L., Hauglustaine, D. A., Rouil, L., and Roemer, M.: Are decadal anthropogenic emission reductions in Europe consistent with surface ozone observations?, Geophys. Res. Lett., 33, L13810, doi:10.1029/2006GL026080, 2006.

Visschedijk, A. J. H., Zandveld, P., and Denier van der Gon, H. A. C.: TNO Report 2007 A-R0233/B: A high resolution gridded European emission database for the EU integrated project GEMS, Netherlands, Organization for Applied Scientific Research, 2007.

Wesely, M. L.: Parameterization of Surface Resistances to Gaseous Dry Deposition in Regional-Scale Numerical Models, Atmos. Environ., 23, 1293-1304, 1989.
Zhang, Q., Jimenez, J. L., Canagaratna, M. R., Allan, J. D., Coe, H., Ulbrich, I., Alfarra, M. R., Takami, A., Middlebrook, A. M., Sun, Y. L., Dzepina, K., Dunlea, E., Docherty, K., De-Carlo, P., Salcedo, D., Onasch, T. B., Jayne, J. T., Miyoshi, T., Shimono, A., Hatakeyama, N., Takegawa, N., Kondo, Y., Schneider, J., Drewnick, F., Weimer, S., Demerjian, K. L., Williams, P. I., Bower, K. N., Bahreini, R., Cottrell, L., Griffin, R. J., Rautianen, J., and Worsnop, D. R.: Ubiquity and dominance of oxygenated species in organic aerosols in anthropogenicallyinfluenced Northern Hemisphere midlatitudes, Geophys. Res. Lett., 34, L13801, doi:10.1029/2007GL029979, 2007. 